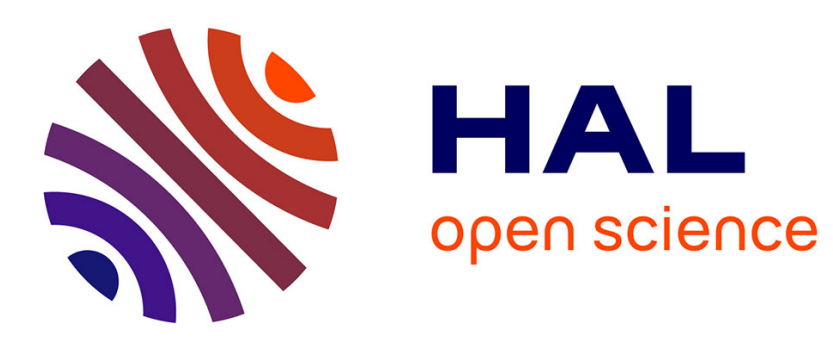

\title{
Regional characteristics of spring Asian dust and its impact on aerosol chemistry over northern China
}

\author{
Y. L. Sun, G. S. Zhuang, Z. F. Wang, Y. Wang, W. J. Zhang, A. H. Tang, X.
} J. Zhao, L. Jia

\section{> To cite this version:}

Y. L. Sun, G. S. Zhuang, Z. F. Wang, Y. Wang, W. J. Zhang, et al.. Regional characteristics of spring Asian dust and its impact on aerosol chemistry over northern China. Atmospheric Chemistry and Physics Discussions, 2006, 6 (6), pp.12825-12864. hal-00302347

\section{HAL Id: hal-00302347 https://hal.science/hal-00302347}

Submitted on 8 Dec 2006

HAL is a multi-disciplinary open access archive for the deposit and dissemination of scientific research documents, whether they are published or not. The documents may come from teaching and research institutions in France or abroad, or from public or private research centers.
L'archive ouverte pluridisciplinaire HAL, est destinée au dépôt et à la diffusion de documents scientifiques de niveau recherche, publiés ou non, émanant des établissements d'enseignement et de recherche français ou étrangers, des laboratoires publics ou privés. 


\section{Regional characteristics of spring Asian dust and its impact on aerosol chemistry over northern China}

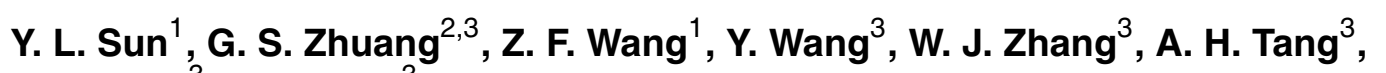
X. J. Zhao ${ }^{3}$, and L. $\mathrm{Jia}^{3}$

${ }^{1}$ NZC/LAPC, Institute of Atmospheric Physics, Chinese Academy of Science, Beijing 100029, China

${ }^{2}$ Center for Atmospheric Chemistry Study, Department of Environmental Science and Engineering, Fudan University, Shanghai 200433, China

${ }^{3}$ Center for Atmospheric Environmental Study, Department of Chemistry, Beijing Normal University, Beijing 100875, China

Received: 7 August 2006 - Accepted: 30 October 2006 - Published: 8 December 2006

Correspondence to: Z. F. Wang (zifawang@mail.iap.ac.cn)

\section{ACPD}

6, 12825-12864, 2006

\section{Regional}

characteristics of spring Asian dust

Y. L. Sun et al.

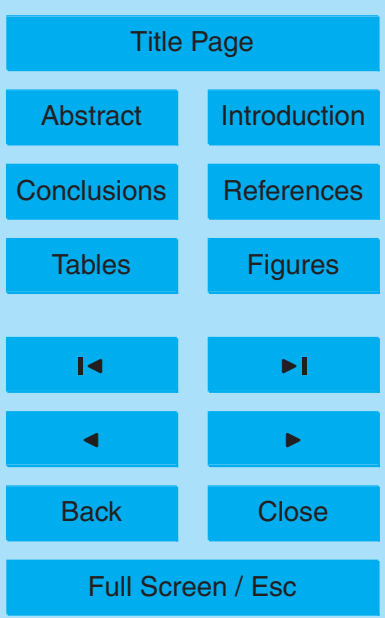

Printer-friendly Version

Interactive Discussion 


\section{Abstract}

TSP and $\mathrm{PM}_{2.5}$ aerosol samples were synchronously collected at six sites along the transport pathway of dust storm from desert regions to coastal areas in the spring of 2004. The aerosol concentration and composition were measured to investigate the

5 regional characteristics of spring Asian dust and its impact on aerosol chemistry over northern China. Based on the daily $\mathrm{PM}_{10}$ concentrations in 13 cities, the northern China could be divided into five regions, i.e., Northern Dust Region, Northeastern Dust Region, Western Dust Region, Inland Passing Region, and Coastal Region. Northern Dust Region was characterized by high content of $\mathrm{Ca}$ and Northeastern Dust Region was characterized by low one instead. Northeastern Dust Region was a relatively clean area with the lowest concentrations of pollutants and secondary ions among all sites. Inland Passing Region and Coastal Region showed high concentrations of pollutants, of which $\mathrm{As}$ and $\mathrm{Pb}$ in Inland Passing Region, and $\mathrm{Na}^{+}, \mathrm{SO}_{4}^{2-}$, and $\mathrm{NO}_{3}^{-}$in Coastal Region were the highest, respectively. The impact of dust on air quality was the greatest in the cities near source regions, and this impact decreased in the order of Yulin/Duolun > Beijing > Qingdao/Shanghai as the increase of transport distance. The spring Asian dust was inclined to affect the chemical components in coarse particles near source regions and those in fine particles in the cities far from source regions. Dust storm could mix significant quantities of pollutants on the pathway and carry them to the downwind cities or dilute the pollutants in the cities over northern China. Each dust episode corresponded to a low ratio of $\mathrm{NO}_{3}^{-} / \mathrm{SO}_{4}^{2-}$ with the lowest value appearing after the peak of dust storm. Asian dust played an important role in buffering and neutralizing the acidity of atmosphere in the cities over northern China, which could lead to the $\mathrm{pH}$ in the aerosols increase $\sim 1$ in spring.

\section{Regional characteristics of spring Asian dust}

Y. L. Sun et al.

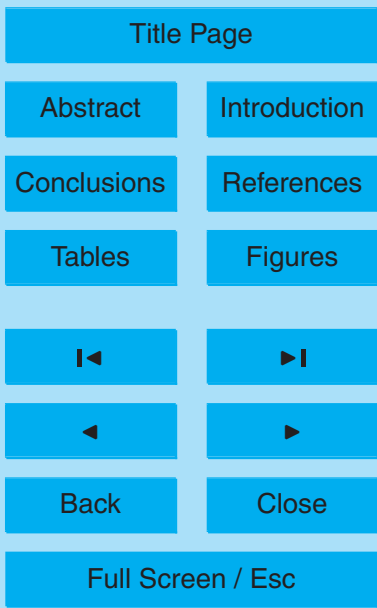

Printer-friendly Version

Interactive Discussion 


\section{Introduction}

Dust storm, picked up by strong winds from Gobi Deserts, has aggrieved northern China for centuries (Zhuang et al., 2001; Sun et al., 2004a). Dust storm also plagues Korea, Japan, the North Pacific Ocean and as far as American Continent through long5 range transport (Duce et al., 1980; Husar et al., 2001; Hee and Soon, 2002; Uematsu et al., 2002). Dust from arid and semi-arid areas of Mongolia and Northern China forms dust clouds and sweeps over most of northern China in a few days. As dust cloud travels downstream, it could mix with industrial pollutants, toxic metals, soot, and gas pollutants on the pathway, and further interact with sea salt when it passes the ocean (Zhang et al., 2003a). The mixing and interactions of dust with pollution aerosol on the pathway affect continuously the size distribution and chemical composition of aerosol (Sun et al., 2005) and then further exerts direct/indirect radiative forcing on climate. It's believed that Asian dust can affect atmospheric chemistry through homogeneous/heterogeneous reactions with anthropogenic pollutants and the global biogeochemical cycle through the long-range transport of nutrients and mineral matter to the terrestrial and ocean (Duce et al., 1980; Zhuang et al., 1992; Jickells et al., 2005). Asian dust and the unique characteristic of pollution in Chinese cities rightly provide a special platform to study the coupling between dust and pollution aerosol.

Dust storm in northern China shows typically regional characteristics. Using a rotated empirical orthogonal function and the annual days of dust storm from 1954 to 1998, Qian et al. (2004) observed five different regions associated with dust storm. They were Xinjiang region, the eastern part of Inner Mongolia, Tsaidam Basin, Tibetan Plateau, and Gobi Deserts near Yellow River. Wang et al. (2005a) also investigated the regional characteristics of dust storm, blowing dust and floating dust in China using the data collected from 701 meteorological observation stations from 1954 to 2004. The three types of dust events showed significantly different spatial distribution. Dust storm occurred the most frequently in the arid and semiarid areas in northern China, and blowing dust and floating dust occurred in both these areas and their neighboring

\section{Regional characteristics of spring Asian dust}

Y. L. Sun et al.

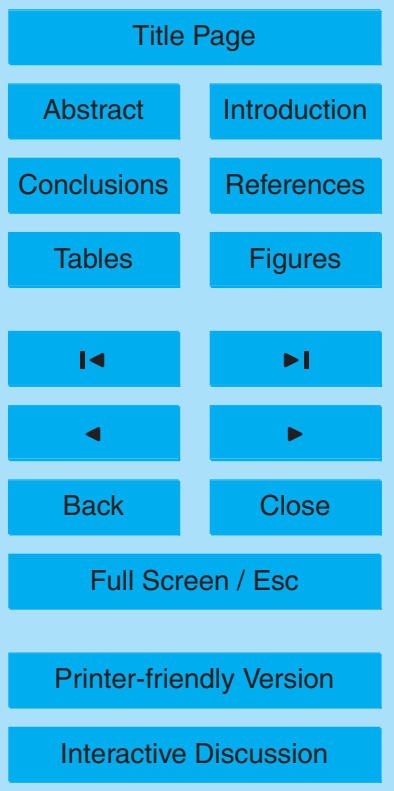


areas. However, the studies above didn't consider the spatial distribution of chemical components in the aerosol. A full knowledge of regional characteristics of spring aerosol is rather limited. Thus, establishing multi-monitoring sites over northern China and carrying out field measurements of aerosols is critical to understand the regional 5 characteristics of spring Asian dust and the mixing of dust with pollution aerosol on the pathway.

The Aerosol Characterization Experiments (ACE-Asia) organized by the International Global Atmospheric Chemistry (IGAC) Program increased our knowledge of the mixing of dust with pollution aerosol. The dust, transported half way around the globe, 10 is not just dust, it is dust mixed with pollution. Air pollution changes dust aerosols in many ways, adding black carbon, toxic materials, and acidic gases to the mineral particles (Huebert et al., 2003). During ACE-Asia campaign, Zhang et al. (2003b) found that the contents of $\mathrm{Ca}$ and $\mathrm{Fe}$ were up to $12 \%$ and $6 \%$, respectively, in Western HighDust source regions, higher than those at other source regions, whereas the content 15 of Al was $~ 7 \%$ among all of major source regions. As such, Arimoto et al. (2004) observed significantly different composition of aerosols between Zhenbeitai in China and Gosan in South Korea. This difference was likely from the different extent of mixing and interaction between dust aerosol and pollution aerosol during the long-range transport. The synchronous monitoring aerosol at desert region and coastal Yellow Sea also suggested the strong spatial variation of trace elements and confirmed the impact of mineral aerosol from northwest desert regions on the distribution of trace elements over Yellow Sea in spring (Liu et al., 2002). However, the previous studies were mostly restricted to either the single sampling site or limited aerosol components, which hardly provide a full-scale understanding of the impact of Asian dust on the chemical composition in different regions of China.

In this study, daily TSP and $\mathrm{PM}_{2.5}$ aerosol samples were collected synchronously at six sampling sites over China in the dust season of 2004. Based on which, the regional characteristics of aerosol components, the compositional difference between dust storm and non-dust storm days, as well as the impact of dust on aerosol chemistry

\section{Regional characteristics of spring Asian dust}

Y. L. Sun et al.

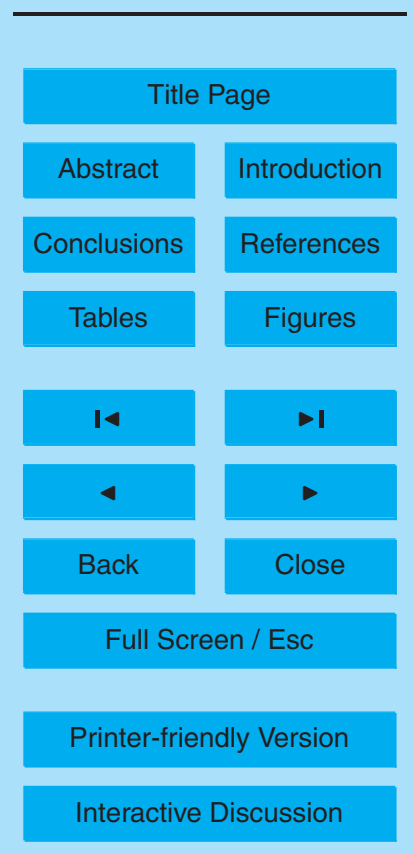


over northern China were investigated. This work would offer the basic data to investigate the mixing of spring Asian dust with pollution aerosol over China and its possible impact on the global biogeochemical cycle.

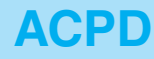

6, 12825-12864, 2006

\section{Experimental methods}

\subsection{Sampling}

Aerosol samples of TSP and $\mathrm{PM}_{25}$ were synchronously collected at Yulin (YL) in Shanxi province, Duolun (DL) in Inner Mongolia, Beijing, including an urban site at Beijing Normal University (BNU) and a suburban site at Miyun (MY), Qingdao (QD), and Shanghai (SH) (see Fig. 1) in the dust season of 2004. The detailed descriptions of these sampling sites were given in Sun et al. (2006). All the aerosol samples were collected on Whatman ${ }^{\circledR} 41$ filters (Whatman Inc., Maidstone, UK) using medium-volume samplers manufactured by Beijing Geological Instrument-Dickel Co., Ltd. (model: TSP/PM $10 / \mathrm{PM}_{2.5}-2$; flow rate: $77.59 \mathrm{~L} \mathrm{~min}^{-1}$ ). The filters before and after sampling were weighed using an analytical balance (Sartorius 2004MP, with a reading precision of $10 \mu \mathrm{g})$ after keeping them in constant temperature $\left(20 \pm 1^{\circ} \mathrm{C}\right)$ and humidity $\left(40^{\circ} \pm 1 \%\right)$ for $48 \mathrm{~h}$.

\subsection{Chemical analysis}

\subsubsection{Element analysis}

The sample filters were digested at $170^{\circ} \mathrm{C}$ for $4 \mathrm{~h}$ in high-pressure Teflon digestion 20

vessel with $3 \mathrm{~mL}$ of concentrated $\mathrm{HNO}_{3}, 1 \mathrm{~mL}$ of concentrated $\mathrm{HCl}$, and $1 \mathrm{~mL}$ of concentrated HF. After cooling, the solutions were dried, and then diluted to $10 \mathrm{~mL}$ with distilled-deionized water. In total, 23 elements (Al, Fe, Mn, Mg, Ti, Sc, Na, Eu, Ce, Sr, $\mathrm{Ca}, \mathrm{Co}, \mathrm{Cr}, \mathrm{Ni}, \mathrm{Cu}, \mathrm{Pb}, \mathrm{Zn}, \mathrm{Cd}, \mathrm{V}, \mathrm{S}, \mathrm{As}$, Se, and Sb) were measured by inductively coupled plasma atomic emission spectroscopy (ICP-AES, Model: ULTIMA, JOBIN-YVON

\section{Regional} characteristics of spring Asian dust

Y. L. Sun et al.

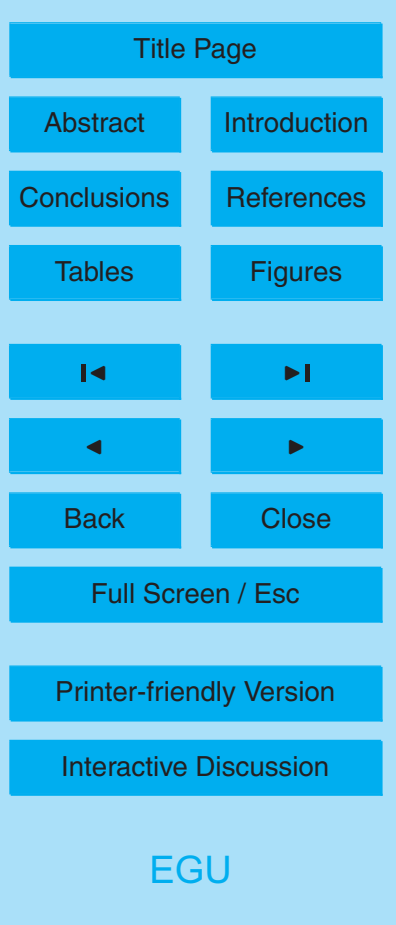


Company, France). The detailed analytical procedures were given elsewhere (Zhuang et al., 2001).

\subsubsection{Ion analysis}

Eleven inorganic ions $\left(\mathrm{SO}_{4}^{2-}, \mathrm{NO}_{3}^{-}, \mathrm{F}^{-}, \mathrm{Cl}^{-}, \mathrm{NO}_{2}^{-}, \mathrm{PO}_{4}^{3-}, \mathrm{NH}_{4}^{+}, \mathrm{Na}^{+}, \mathrm{K}^{+}, \mathrm{Ca}^{2+}, \mathrm{Mg}^{2+}\right)$ 5 and 4 organic acids (acetic, formic, oxalic, and methylsulfonic acid (MSA)) were analyzed by lon Chromatography (IC, Dionex 600) that consists of a separation column (Dionex lonpac AS11 for anion and CS12A for cation), a guard column (Dionex lonpac AG 11 for anion and AG12A for cation), a self-regenerating suppressed conductivity detector (Dionex lonpac ED50) and a gradient pump (Dionex lonpac GP50). The details were given elsewhere (Yuan et al., 2003).

\subsection{3 $\mathrm{PM}_{10}$ data}

Air pollution index (API) data in 13 cities over northern China (see Fig. 1) during MarchApril in 2004 was obtained from State Environmental Protection Administration of China (http://www.zhb.gov.cn/quality/air.php3). API was converted to $\mathrm{PM}_{10}$ concentration according to the following formula:

$\left.C=C_{\text {low }}+\left[\left(I-I_{\text {low }}\right) / I_{\text {high }}-I_{\text {low }}\right)\right] \times\left(C_{\text {high }}-C_{\text {low }}\right)$

where $C$ is the concentration of $\mathrm{PM}_{10}$ and $/$ is the API value of $\mathrm{PM}_{10} . I_{\text {high }}$ and $I_{\text {low }}$, the two values most approaching to value $I$ in the API grading limited value table, stand for the value larger and lower one than $I$, respectively; $C_{\text {high }}$ and $C_{\text {low }}$ represent the $\mathrm{PM}_{10}$ concentration corresponding to $I_{\text {high }}$ and $I_{\text {low }}$, respectively.

\section{Regional \\ characteristics of spring Asian dust}

Y. L. Sun et al.

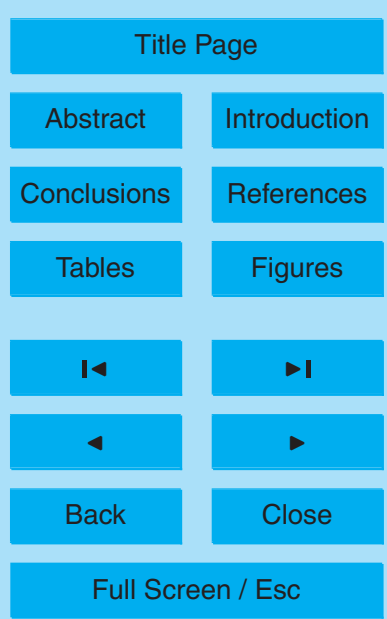

Printer-friendly Version

Interactive Discussion 


\section{Results and discussion}

\subsection{Dust episodes}

Two dust storms occurred over northern China in the spring of 2004. One was from 9-11 March (DS1), and the other was from 27-30 March (DS2). Specifically, 28-29

5 March at BNU, 9 March and 28-29 March at MY, 9 March and 27-28 March at DL, 9-10 March and 29 March at YL, 10 March and 30 March at QD, and 10 March and 30 March at $\mathrm{SH}$ were defined as dust storm days in this study. Dust storm leads to heavy particulate pollution over northern China. Inhalable particles $\left(\mathrm{PM}_{10}\right)$ are, consequently, the primary pollutants in the cities over northern China in spring. Most of the cities in 10 northern China experienced the first dust peak on 9 March. The air pollution index (API) in Lanzhou, Xining, Hohhot, and Beijing reached up to $500\left(>600 \mu \mathrm{g} \mathrm{m}^{-3}\right.$, called "heavy pollution") on that day (Daily report of air quality by State Environmental Protection Administration of China). As dust storm transported to Qingdao and Shanghai on 10 March, the concentration of $\mathrm{PM}_{10}$ in the two cities was also much elevated. The strength of dust storm on 28-30 March was relatively weaker as compared to DS1 and the concentration of $\mathrm{PM}_{10}$ in most of cities over northern China was in the range of $200-400 \mu \mathrm{g} \mathrm{m}^{-3}$.

\subsection{Regional division of the areas over northern China}

Results from factor analysis of the $\mathrm{PM}_{10}$ concentration in 13 cities over northern China 20 in the spring (see Table 1) basically reflected the regional characteristics of spring Asian dust. The first factor showed high loadings for the cities of Lanzhou, Xinning, Yinchuan, and Xi'an, most of which are located in central/west of Inner Mongolia and close to Tengger Desert, Badain Juran Desert, and Mu Us Desert. This region was named as Northern Dust Region. The second factor was associated with Qingdao, Shanghai, and Shenyang. These three cities are mainly located in the coastal area, which was named as Coastal Region. Most of the cities in the third factor, such as Bei-

\section{Regional characteristics of spring Asian dust}

Y. L. Sun et al.

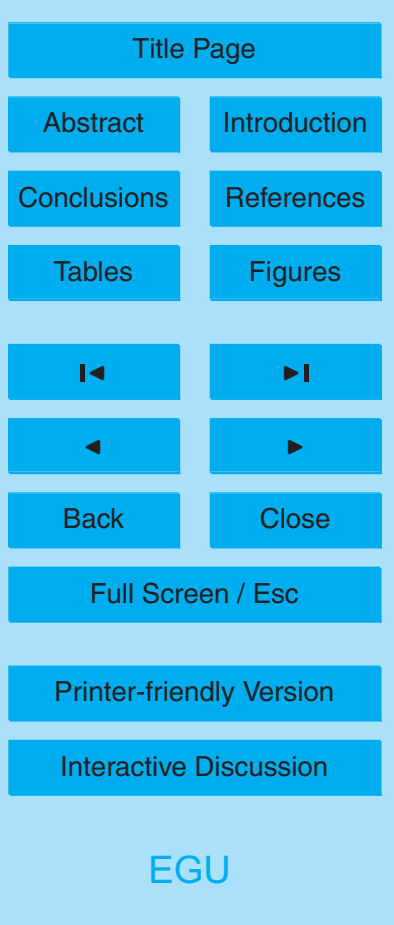


jing, Taiyuan, and Shijiazhuang are located on the transport pathway of dust storm to downstream region. The region they are located in were named as Inland Passing Region. Urumchi showed a high loading in the fourth factor, representing Western-Dust Region, where Takalimakan Desert and Gurbantunggut Desert are located. Another

5 region named as Northeastern Dust Region is located near Hunshandake Sandy Land and Horqin Sandy Land, where the report of air quality has not been set up yet. The five regions described above are shown in Fig. 1. The sampling sites in this study are just distributed over the four regions above, which provides the basis to study the regional characteristics of spring Asian dust over northern China.

\subsection{Regional characteristics of spring aerosols over northern China}

The aerosols in northern China are mainly composed of mineral matter, organic material, and secondary sulfate and nitrate (He et al., 2002; Sun et al., 2004b). The chemical composition of aerosols shows obvious regionality due to the significant differences of economic development, energy consumption, geographical location, and 15 metrological conditions in different regions. Generally, comparing the "mean" values is the simplest way in estimating the compositional differences of aerosol in different regions. However, the sampling in this study was concentrated in the dust season. Therefore the "mean" values would be greatly influenced by the peak concentrations of chemical species in dust storm days, and even would not reveal the true status of regional difference sometimes. Here, in view of statistics, the "median" values could be more reasonable to be used in such a study. Consequently, the following discussions on regional variations of chemical components were mainly based on the differences of their "median" values. The chemical species were divided into six groups for the convenience of study: (1) mineral elements, including $\mathrm{Ca}, \mathrm{Al}, \mathrm{Fe}, \mathrm{Na}, \mathrm{Mg}$, and Ti; (2) 25 pollution elements, including $\mathrm{As}, \mathrm{Zn}, \mathrm{Pb}$, and $\mathrm{Cu}$; (3) other elements, including $\mathrm{Mn}, \mathrm{V}$, $\mathrm{Ni}, \mathrm{Sr}$, and $\mathrm{Cr}$; (4) mineral ions, including $\mathrm{Na}^{+}, \mathrm{Ca}^{2+}$, and $\mathrm{Mg}^{2+}$; (5) secondary ions, including $\mathrm{NH}_{4}^{+}, \mathrm{NO}_{3}^{-}$, and $\mathrm{SO}_{4}^{2-} ;(6)$ other ions, including $\mathrm{K}^{+}, \mathrm{F}^{-}$, and $\mathrm{Cl}^{-}$.

\section{ACPD}

6, 12825-12864, 2006

\section{Regional characteristics of spring Asian dust}

Y. L. Sun et al.

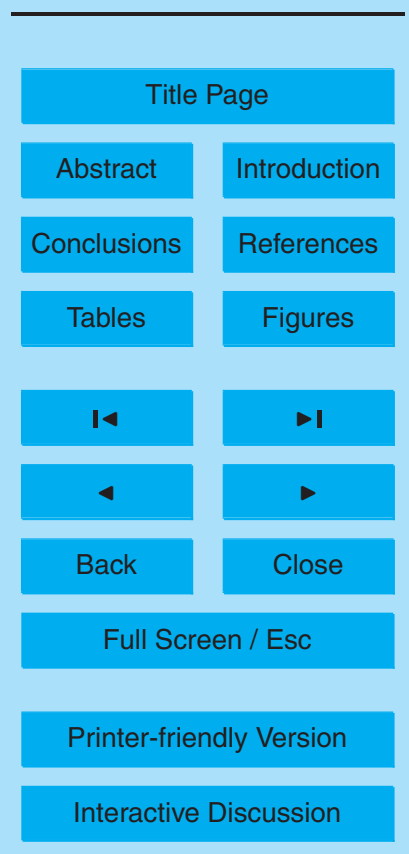




\subsubsection{Regionality suggested by mineral elements}

Figure 2 presents the spatial variations of major mineral elements, $\mathrm{Fe}, \mathrm{Al}, \mathrm{Ca}$, and $\mathrm{Mg}$ in TSP and $\mathrm{PM}_{2.5}$. The results of One-way ANOVA test $(p<0.05)$ indicated that $\mathrm{Fe}$ and Al did not show, but Ca did, significantly different spatial variations among all sites.

5 BNU showed the highest median concentrations of Fe, Al, and Mg in TSP, and YL was the second, and QD was the lowest. The concentrations of mineral elements at BNU were 2-4 times higher than those at QD. These elements were usually associated with crustal sources such as road dust, soil dust and construction dust (Sun et al., 2004b). The high concentrations of mineral elements at BNU could be related to more road dust caused by wind and motor vehicles. The higher relative humidity and more precipitation in spring (see Table 2) at QD and $\mathrm{SH}$ in Coastal Region inhibited the re-suspension of road dust, which could lead to the lower concentrations of mineral elements. The high concentrations of mineral elements at $Y L$ could be associated with the dust from deserts nearby plus local road dust. However, though DL in Northeastern Dust Region is frequently affected by the dust accompanied with cold fronts, it did not show very high median concentrations of mineral elements. DL is a small town with much fewer motor vehicles than those cities located in the eastern developed areas, and therefore it would have much less mineral aerosols from the road dust. Compared with those in TSP, the spatial distributions of mineral elements in $\mathrm{PM}_{2.5}$ were relatively simple. $\mathrm{Fe}, \mathrm{Al}$, and $\mathrm{Mg}$ showed relatively even distributions at four sites, $\mathrm{YL}, \mathrm{DL}, \mathrm{BNU}$, and MY, and all much higher than those at other two sites, QD and SH.

The case of $\mathrm{Ca}$ was much different from the three elements mentioned above. Ca showed strong regionality in both TSP and $\mathrm{PM}_{2.5}$. In TSP, the median concentration of $\mathrm{Ca}$ was in the order of $\mathrm{BNU}>\mathrm{YL}>\mathrm{SH}>\mathrm{MY}>\mathrm{QD}>\mathrm{DL}$. The mass percentage of $\mathrm{Ca}$ at $\mathrm{YL}$ was $8.1 \%$, which was close to the values of $7 \%$ at the northern high-dust source areas and $8 \%$ at loess area (Zhang et al., 2003b), while it was only $3.7 \%$ at DL, much lower than those at other regions. In addition, the mass percentage of $\mathrm{Ca}$ was all higher than the soil background value (1\%-2\%) in northeastern China (Zheng, 1994). These

\section{Regional characteristics of spring Asian dust}

Y. L. Sun et al.

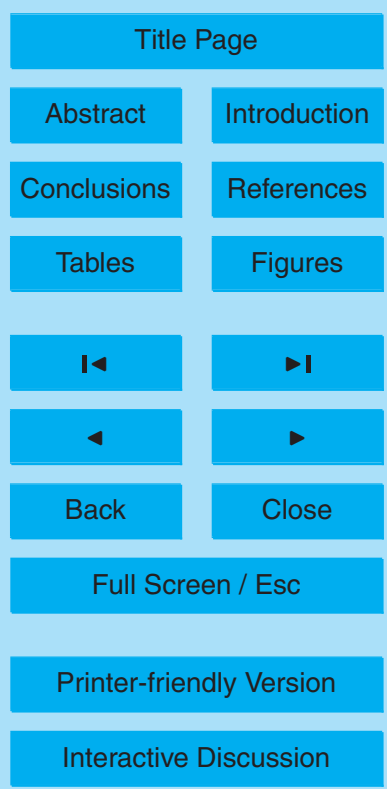


results indicated that Northern Dust Region was characterized by high content of Ca, and Northeastern Dust Region, was characterized by low one instead. The high concentration of $\mathrm{Ca}$ in $\mathrm{BJ}$ and $\mathrm{SH}$ was likely due to local construction dust, as $\mathrm{Ca}$ is usually an indicator of construction dust. The spatial variations of $\mathrm{Ca}$ in $\mathrm{PM}_{2.5}$ were somewhat 5 different from those in TSP. YL and BNU showed higher median concentrations than other sites, while QD and SH were characterized by lower concentrations. The different spatial variations of $\mathrm{Ca}$ between TSP and $\mathrm{PM}_{2.5}$ could be likely due to the different distribution of $\mathrm{Ca}$ in coarse and fine particles.

Table 3 further shows the ratios of $\mathrm{Fe}, \mathrm{Mg}$, and $\mathrm{Ca}$ to $\mathrm{Al}$ in different regions of China. 10 The ratios of Fe/Al at YL, DL, MY, and QD were lower than those in BJ and $\mathrm{SH}$, but all close to 0.62 in earth's crust (Mason and Moore, 1982) and 0.65 in Northern Dust region in China (Zhang et al., 2003b). The high values of Fe/Al in BJ and SH were likely due to the emission from steel industry in the two cities, such as Capital Steel Group in Beijing and Baoshan Steel Group Corporation in Shanghai, the large sources of $\mathrm{Fe}$ in the aerosol. Like $\mathrm{Ca}$ concentrations described above, the distribution of $\mathrm{Ca} / \mathrm{Al}$ ratio was also much different from Fe/Al. The ratio of $\mathrm{Ca} / \mathrm{Al}$ was in the order of $\mathrm{BNU}>\mathrm{YL}>\mathrm{SH}>\mathrm{MY}>\mathrm{QD}>\mathrm{DL}$ in TSP and $\mathrm{YL}>\mathrm{BNU}>\mathrm{SH}>\mathrm{MY}>\mathrm{QD}>\mathrm{DL}$ in $\mathrm{PM}_{2.5} . \mathrm{Ca} / \mathrm{Al}$ ratios of 1.64 in TSP and 1.71 in $\mathrm{PM}_{2.5}$ at $\mathrm{YL}$ were consistent with those (1.48 at $\mathrm{YL}$ and 1.97 at Dingbian near Mu Us Desert) reported previously by Zhang et al. (1997), and the ratios of $\mathrm{Ca} / \mathrm{Al}$ of 0.61 in TSP and 0.79 in $\mathrm{PM}_{2.5}$ at DL were similar to 0.64 in TSP collected during dusty days at Sanggen Dalai near Hunshandake Sandy Land (Cheng et al., 2005). These results confirmed further the characteristics of high content of $\mathrm{Ca}$ in Northern Dust Region and low one in Northeastern Dust Region. Additionally, the ratios of $\mathrm{Ca} / \mathrm{Al}$ at both Northern Dust Region and Northeastern Dust Region were lower than that in Western Dust Region (>2.0\%, Table 3) (Zhang et al., 2003b; Makra et al., 2002), but much higher than 0.45 in earth's crust (Mason and Moore, 1982). As mentioned above, the high ratio of $\mathrm{Ca} / \mathrm{Al}$ at $\mathrm{BNU}$, close to those reported by $\mathrm{He}$ et al. (2001), could be related to the local construction dust. Overall, the high ratio of $\mathrm{Ca} / \mathrm{Al}$ in this study indicated that the soils in northern China were enriched with $\mathrm{Ca}$

\section{Regional characteristics of spring Asian dust}

Y. L. Sun et al.

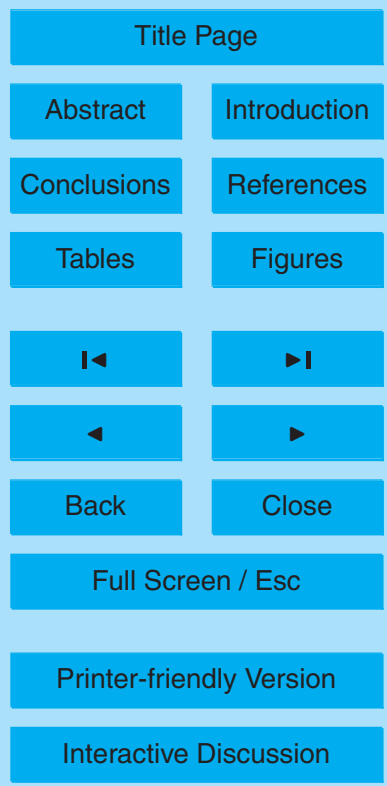

EGU 
(Hseung and Jackson, 1952) compared with other sites over the world. Furthermore, the strong regionality of $\mathrm{Ca} / \mathrm{Al}$ over northern China could be used as element tracer to identify the sources of dust storm.

\subsubsection{Regionality suggested by pollution elements}

5 The pollutants in the aerosol are strongly influenced by the local pollution sources of cities plus those brought by dust storm, and hence the distributions of pollution elements are more complicated than mineral elements. Figure 3 presents the spatial variations of pollution elements, $\mathrm{As}, \mathrm{Zn}, \mathrm{Pb}$, and $\mathrm{Cu}$. An obvious characteristic of the spatial distribution was that the concentrations of pollution elements at DL in Northeastern Dust Region were distinctively lower than those at other regions. The other was that the median concentrations of pollution elements in the costal developed cities, such as $\mathrm{QD}$ and $\mathrm{SH}$, and the inland city, $\mathrm{BJ}$, were ubiquitously higher than those near source regions, and it was much more obviously in the fine particles. The sampling sites near source regions are close to the deserts or sandy lands with rare anthropogenic sources nearby, and the frequent cold fronts also favor the clear-out of pollutants in these cities. Thus, the pollution level of atmosphere near source regions is low. The spatial variations of pollution elements among the other four sites were also significantly different. Specifically, As and $\mathrm{Pb}$ at BNU, $\mathrm{Zn}$ at QD, Cu at $\mathrm{SH}$ showed the highest concentration, respectively. The rapid increase of motor vehicles plus coal combustion for domestic heating in spring both contributed to the high concentrations of $\mathrm{As}$ and $\mathrm{Pb}$ in the atmosphere of Beijing. The high concentrations of $\mathrm{Zn}$ at $\mathrm{QD}$ and $\mathrm{Cu}$ at $\mathrm{SH}$ were likely associated with the local pollution sources.

Enrichment factor $\left(\mathrm{EF}, \mathrm{EF}=(\mathrm{X} / \mathrm{Al})_{\text {aerosol }} /(\mathrm{X} / \mathrm{Al})_{\text {crust }}\right.$, $\mathrm{Al}$ is a reference element from Taylor and McLennan, 1995) is usually used to estimate the contribution of anthropogenic 25 source to a certain element (Choi et al., 2001). Figure 4 shows that the EFs of Cu, Zn, and $\mathrm{Pb}$ at $\mathrm{DL}$ in Northeastern Dust Region were 10 , much lower that those at other regions, which indicated that these elements were less influenced by anthropogenic sources. Comparatively, the EF of As at DL was 60 in TSP and up to 240 in $\mathrm{PM}_{2.5}$.

\section{Regional characteristics of spring Asian dust}

Y. L. Sun et al.

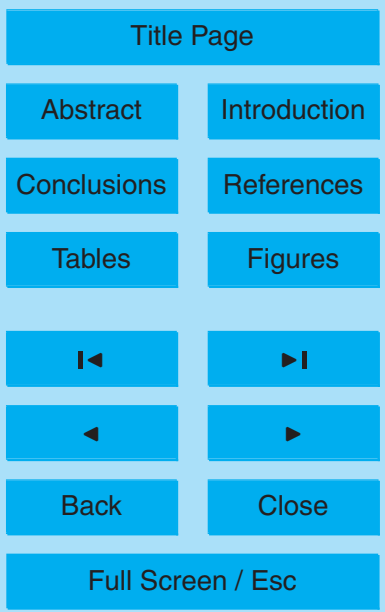

Printer-friendly Version

Interactive Discussion 
This could be likely due to the high content of As in the soil of northern China (Wei et al., 1999) or coal combustion in the local areas. Overall Northeastern Dust Region is defined as a relatively clean region. When dust storm passed through this region, it would not mix many pollutants in this region, but exert more effect of dilution on the at5 mosphere of downwind cities (Guo et al., 2004). Both located near desert regions, YL in Northern Dust Region showed higher EFs of pollution elements than DL, which was likely due to the pollutants transported from the urban of $Y L$, where three large coal mines are located (http://www.ylei.cn/). The higher EFs of pollution elements at QD and $\mathrm{SH}$ in Coastal Region than other regions could be caused by (1) dust storm could 10 mix more pollutants and carry them to $\mathrm{QD}$ and $\mathrm{SH}$ after passing a longer transport distance; (2) the dilution effect of dust in spring on the pollutants in the cities far from source regions was weak, and hence more pollutants from the local pollution sources in these two cities remained. More clearly, the pollution elements were more enriched in fine particles, as suggested by the higher EFs of pollution elements in $\mathrm{PM}_{2.5}$ than 15 TSP. The pollutants in Inland Passing Region, which is closer to source regions than Coastal Region, were more diluted and cleared out by cold air fronts, which led to the lower EFs of pollution elements than those at Coastal Region. Overall, the pollution elements in spring aerosols showed a more obvious regionality along Desert RegionInland Passing Region-Coastal Region as compared to mineral elements, and this regionality was characterized by increasing EFs of pollution elements in $\mathrm{PM}_{2.5}$ in the order of Coastal Region (QD/SH) > Inland Passing Region (BNU/MY) > Northern Dust Region (YL) > Northeastern Dust Region (DL).

\subsubsection{Regionality suggested by water-soluble ions}

Figure 5 presents the spatial variations of $\mathrm{Na}^{+}, \mathrm{Mg}^{2+}, \mathrm{Ca}^{2+}$, and $\mathrm{K}^{+}$. Similar to the 25 elements mentioned above, the concentrations of major mineral ions at $\mathrm{DL}$ in Northeastern Dust Region were distinctively lower than those at other regions. In the case of $\mathrm{Na}^{+}$, the concentration decreased in the order of $\mathrm{QD}>\mathrm{YL} / \mathrm{SH}>\mathrm{BNU}>\mathrm{MY}>\mathrm{DL}$. $\mathrm{Na}^{+}$was significantly correlated with Al, an indicator of mineral matter (Arimoto et al., 2004), in

\section{Regional characteristics of spring Asian dust}

Y. L. Sun et al.

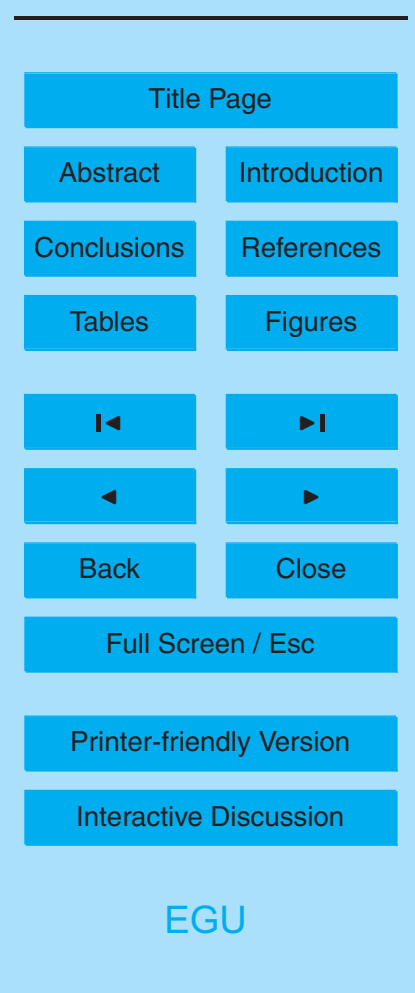


both TSP and $\mathrm{PM}_{2.5}$ at $\mathrm{YL}$ and BNU (correlation coefficient $r=0.75-0.87$ ). However, $\mathrm{Na}^{+}$and Al showed weaker, though still significant relationship at $Q D(r=0.60)$ and $\mathrm{SH}$ $(r=0.77)$ in $\mathrm{PM}_{2.5}$. Thus, the high concentrations of $\mathrm{Na}^{+}$at $\mathrm{QD}$ and $\mathrm{SH}$ were likely from the crustal source plus sea salt from the ocean (Zhang et al., 2001). At DL, $\mathrm{Na}^{+}$showed 5 weaker correlations with $\mathrm{Al}$ ( $r$ was 0.40 and 0.52 for TSP and $\mathrm{PM}_{2.5}$, respectively) as compared with those at $\mathrm{YL}$ and BNU, which was likely related to the dried salt-lakes saline soils in arid and semi-arid areas enriched by chloride and sulfate (Zhang et al., 2004). The spatial variations of ions, $\mathrm{Mg}^{2+}$ and $\mathrm{Ca}^{2+}$, were similar to those of elements, $\mathrm{Mg}$ and $\mathrm{Ca}$. Their concentrations were in the order of $\mathrm{YL} / \mathrm{BNU}>\mathrm{MY}>\mathrm{QD} / \mathrm{DL}$. $10 \mathrm{~K}^{+}$is usually considered as an indicator of biomass burning. The spatial variation of $\mathrm{K}^{+}$was much different from those mineral ions. The highest concentrations of $\mathrm{K}^{+}$at $\mathrm{BNU}$ and $\mathrm{MY}$ in both TSP and $\mathrm{PM}_{2.5}$ were clearly associated with the biomass burning in Beijing and its surrounding areas (Duan et al., 2004). QD/SH was in the second of $\mathrm{K}^{+}$concentration, and $\mathrm{YL}$ and $\mathrm{DL}$ showed the lowest one.

15 Sulfate and nitrate are mainly from the heterogeneous/homogeneous reactions of their precursors of $\mathrm{SO}_{2}$ and $\mathrm{NO}_{\mathrm{x}}$. Sulfate and nitrate have become important components of aerosols in the cities accompanied with rapid motorization and modernization (He et al., 2001; Sun et al., 2004b). The median concentration of sulfate in TSP increased in the order of $\mathrm{MY}<\mathrm{BNU}<\mathrm{QD}<\mathrm{SH}$ (see Fig. 6). $\mathrm{YL}$ and $\mathrm{DL}$ showed relatively lower concentrations of secondary aerosols than those in other four sites. The amount of motor vehicles and coal combustion in these two cities were much less than other developed cities in the east of China, and in turn, the emission of pollution gases $\mathrm{SO}_{2}$ and $\mathrm{NO}_{\chi}$ near dust source regions was also much less than Coastal Region. Additionally, the air near dust source regions in spring was dry and the relative humidity $25(\mathrm{RH})$ was only $25.2 \%$ and $33.8 \%$ at $\mathrm{YL}$ and $\mathrm{DL}$ respectively (see Table 2 ), which was not favorable for the secondary transformation of $\mathrm{SO}_{2}$ and $\mathrm{NO}_{\mathrm{x}}$. Both these factors led to the low concentrations of secondary aerosols near dust source regions. Comparatively, the large emission of $\mathrm{NO}_{\mathrm{x}}$ from motor vehicles and $\mathrm{SO}_{2}$ from coal combustion plus the relatively wet air with the $\mathrm{RH}$ more than $60 \%$ (see Table 2 ) contributed to the

\section{Regional characteristics of spring Asian dust}

Y. L. Sun et al.

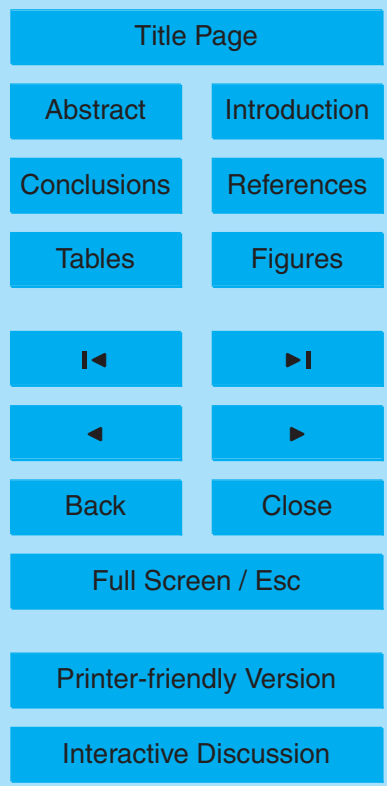

EGU 
high concentrations of secondary aerosols at Coastal Region (QD/SH). BJ had more vehicles, but the climate was drier than QD and $\mathrm{SH}$, therefore BJ showed lower concentrations of secondary aerosols than $\mathrm{QD}$ and $\mathrm{SH}$, but higher than $\mathrm{YL}$ and $\mathrm{DL}$. The spatial distribution of nitrate in $\mathrm{PM}_{2.5}$ was much different from that in TSP. BNU was the 5 highest, and QD was the second, and SH/DL was the lowest.

The ratio of $\mathrm{NO}_{3}^{-} / \mathrm{SO}_{4}^{2-}$ is commonly used to indicate the relative contribution of stationary and mobile sources (Arimoto et al., 1996). Higher $\mathrm{NO}_{3}^{-} / \mathrm{SO}_{4}^{2-}$ ratio suggests more contribution from mobile sources. Figure 7 shows the ratio of $\mathrm{NO}_{3}^{-} / \mathrm{SO}_{4}^{2-}$ and the concentration of $\mathrm{Al}$ at the six sampling sites in spring of 2004. It was clearly shown that 10 (1) the ratios of $\mathrm{NO}_{3}^{-} / \mathrm{SO}_{4}^{2-}$ near dust source regions (YL/DL) were much lower than those at other regions, which indicated that the pollution from mobile sources such as vehicle exhaust at these two sites was much less than that from stationary sources; (2) corresponding to each dust episode, the ratio of $\mathrm{NO}_{3}^{-} / \mathrm{SO}_{4}^{2-}$ was low, moreover the lowest value appeared after the peak of dust episode. As dust storm passed through 15 Northern Dust Region and Northeastern Dust Region characterized by the low ratio of $\mathrm{NO}_{3}^{-} / \mathrm{SO}_{4}^{2-}$, it would mix with the aerosol in the cities, then the pollution aerosols would be diluted and the ratio of $\mathrm{NO}_{3}^{-} / \mathrm{SO}_{4}^{2-}$ in the aerosol would decrease. Besides, $\mathrm{HNO}_{3}$ can react with aqueous carbonates on soil particles to form coarse mode nitrate through the following reaction (Mamane and Gottlieb, 1992) that could represent 20 a significant sink for $\mathrm{NO}_{\mathrm{x}}$.

$2 \mathrm{HNO}_{3}(g)+\mathrm{CaCO}_{3}(s) \rightarrow \mathrm{Ca}\left(\mathrm{NO}_{3}\right)_{2}(s)+\mathrm{H}_{2} \mathrm{O}+\mathrm{CO}_{2}(g)$

The dry deposition of coarse mode nitrate would contribute to the lower concentration of nitrate in dust storm, and in turn the lower concentration of nitrate after dust peaks lead to the lower ratio of $\mathrm{NO}_{3}^{-} / \mathrm{SO}_{4}^{2-}$.

\subsection{Impact of dust on aerosol chemistry over northern China}

The impact of dust on the chemical composition of aerosols in the cities can be estimated by comparing the compositional differences between dust storm and non-dust

\section{Regional characteristics of spring Asian dust}

Y. L. Sun et al.

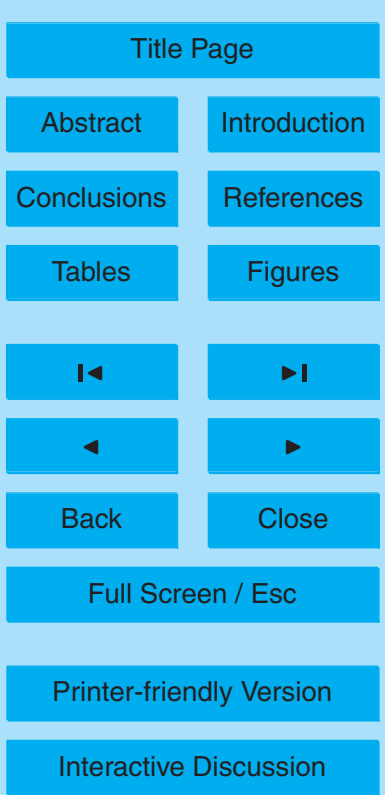

EGU 
storm days. Two dust episodes, DS1 and DS2 observed in the dust season of 2004 showed significantly different impacts on aerosol chemistry of the cities due to their different sources, transport pathways, strength, of which DS1 on QD, DS2 on YL and DL were the severest.

\section{3.4.1 Impact of dust on Northern Dust Region and Northeastern Dust Region}

The compositional differences between dust storm and non-dust storm days at the two sites are shown in Fig. 8. Clearly, the impact of dust on the mineral components in the aerosols at DL and YL was more evident than that at other sites (see below). The concentrations of most mineral elements in both TSP and $\mathrm{PM}_{2.5}$ in DS2 at DL 10 were 7-15 times, (Fe was even up to 25 times) higher than those in non-dust storm days, and the mineral ions were also $\sim 5$ times higher than those in non-dust storm days. The impact of DS2 on other chemical species in TSP was different from those in $\mathrm{PM}_{2.5}$. The concentrations of pollution elements in TSP in DS2 increased 5-10 times compared with that in non-dust storm days, while the ions, $\mathrm{F}^{-}$and $\mathrm{Cl}^{-}$were basically 15 unchanged, and $\mathrm{NH}_{4}^{+}$and $\mathrm{NO}_{3}^{-}$decreased instead. Differently, the pollution elements in $\mathrm{PM}_{2.5}$ were elevated 2-3 times, and $\mathrm{F}^{-}, \mathrm{Cl}^{-}, \mathrm{SO}_{4}^{2-}$ and $\mathrm{NO}_{3}^{-}$were $\sim 4$ times elevated in DS2. These results indicated that the impact of dust on the pollution elements in TSP was more significant than those in $\mathrm{PM}_{2.5}$. Similar results were also observed in DS1 at DL. The impact of DS1 on the pollution elements in TSP was a factor of 20 1.3-6.0 higher than that in $\mathrm{PM}_{2.5}$. Generally, the pollution elements from pollution sources were more enriched in fine particles, while those from crustal sources were more concentrated in coarse particles. This would confirm further that dust itself was an important source of the pollution elements in the aerosols near dust source regions, which was also consistent with the results mentioned in Sect. 3.3. The different impact of dust on the secondary ions between TSP and $\mathrm{PM}_{2.5}$ was likely due to the faster sedimentation of coarse particles where nitrate and sulfate present (Nishikawa et al., 1991). Compared with DS2, the strength of DS1 was relatively weaker, so the impact

\section{Regional characteristics of spring Asian dust}

Y. L. Sun et al.

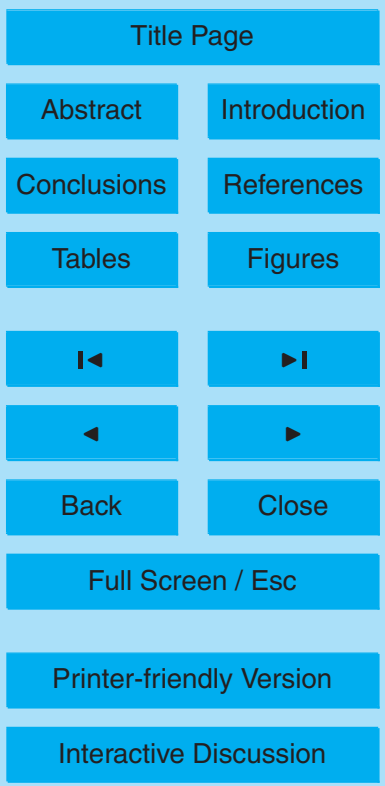

EGU 
of dust on aerosol chemistry of DL is correspondingly weaker. The concentrations of chemical components except the pollution elements and the ions $\mathrm{Na}^{+}$, and $\mathrm{Cl}^{-}$in both TSP and $\mathrm{PM}_{2.5}$ in dust storm were generally 2-3 times as high as that in non-dust storm days.

5 Compared with DL, the mineral and pollution elements in TSP in DS1 at YL were 4-7 and 2-3 times, respectively, higher than those in non-dust storm days, and the mineral and secondary ions were both 2-4 times higher than those in non-dust storm days. The impact of dust on the chemical components in $\mathrm{PM}_{2.5}$ was relatively even. Most of them were basically 2-3 times elevated in DS1 except that the secondary ions showed a little 10 lower concentration as compared to non-dust storm days. In comparison, dust exerted a stronger impact on the mineral species in DS2 than those in DS1. For example, the mineral elements were 6-9 times in TSP and 4-5 times in $\mathrm{PM}_{2.5}$ elevated in DS2. Figure 8 also showed that the impact of dust storm at $Y L$ on the mineral and pollution elements in TSP was more significant than those in fine particles. The pollution elements in TSP

15 were $\sim 3$ times elevated, but only 1-2 times in $\mathrm{PM}_{2.5}$. Differently, dust storm exerted approximately the same impact on the ionic components in TSP and $\mathrm{PM}_{2.5}$.

\subsubsection{Impact of dust on Inland Passing Region}

Figure 9 presents the comparison of chemical composition between dust storm and non-dust storm days at BNU and MY in Inland Passing Region. As shown in Fig. 9, dust 20 storm showed the greatest impact on the mineral species in both TSP and $\mathrm{PM}_{2.5}$. The concentrations of mineral elements and mineral ions in DS2 at BNU and MY were both 2-5 times higher than those in non-dust storm days, while the pollution elements and secondary ions decreased correspondingly. The typical characteristic of dust storm is the large quantities of dust transported from the source areas. When dust storm passes 25 through the cities, it could be coupled and interact with the components in the atmosphere of cities, which leads to the chemical composition of aerosol more complicated. Guo et al. (2004) found that dust itself could be an important source of some pollution elements. However, dust storm usually accompanied with strong winds, dry and cold

\section{Regional characteristics of spring Asian dust}

Y. L. Sun et al.

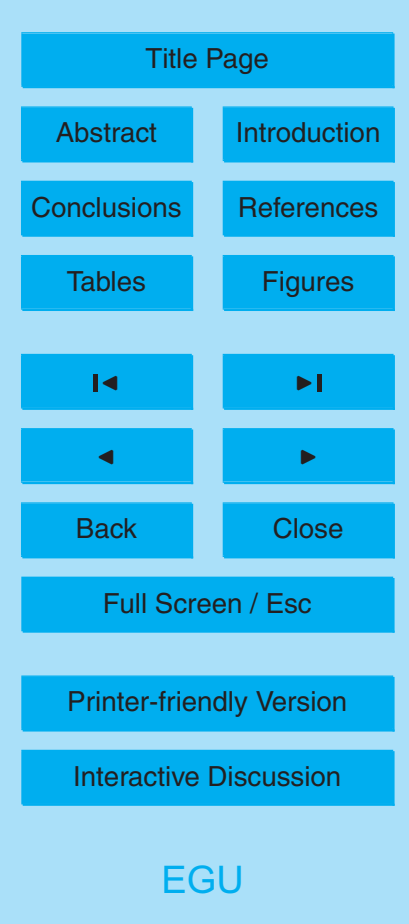


air mass, and low $\mathrm{RH}$, also benefits the dilution of pollutants. Therefore though dust storm brings significant quantities of pollutants from the pathway, it dilutes some pollutants from local sources at the same time. Also, the alkalinity of dust aerosols, mainly determined by the calcium carbonate content greatly benefits the uptake of pollution

5 gases, such as $\mathrm{SO}_{2}$ and $\mathrm{NO}_{\mathrm{x}}$ and favors the deposition of them (Sun et al., 2005). Overall, if the process of dilution is dominant, the concentrations of pollutants in dust storm will be lower than those in non-dust storm days. Contrarily, the concentrations of pollutants in dust storm will be higher than those in non-dust storm days. An interesting case was observed, i.e. the impact of dust on the mineral components in $\mathrm{PM}_{2.5}$ 10 at BNU and MY was more significant than those in TSP. It could be likely due to the gravitational deposition of large particles during the long-range transport, while fine particle could be transported longer distance for its longer residence time in the atmosphere. Compared with DS2, nearly all chemical components in TSP and $\mathrm{PM}_{2.5}$ in DS1 were 2-5 times and 2-3 times, respectively, higher than those in non-dust storm days. 15 DS1 carried more pollution elements and more secondary ions than DS2, that is, DS1 benefited the accumulation of pollutants, while DS2 favored the dilution of pollutants.

\subsubsection{Impact of dust on Coastal Region}

Both QD and SH are located in Coastal Region. QD is the place where dust storm passes frequently, while $\mathrm{SH}$ is less influenced by dust storm instead. During DS1 at 20 QD, the mineral elements in TSP and $\mathrm{PM}_{2.5}$ were 4-8 and 4-12 times, respectively, higher than that in non-dust storm days, and the mineral ions were also 2-4 times elevated in both TSP and $\mathrm{PM}_{2.5}$. The pollution elements in both TSP and $\mathrm{PM}_{2.5}$ were in the same level (except As and $\mathrm{Cu}$, a little higher) as those in non-dust storm days. The secondary ions in DS1 generally decreased instead. Compared with DS1, DS2 25 showed less impact on the chemical components in the aerosols at QD. The mineral elements increased a factor of 2-4, and the mineral ions were basically unchanged, and the pollution elements and the secondary ions decreased instead. Figure 10 clearly indicated that the impact of dust on the mineral components in $\mathrm{PM}_{2.5}$ was remarkably

\section{Regional characteristics of spring Asian dust}

Y. L. Sun et al.

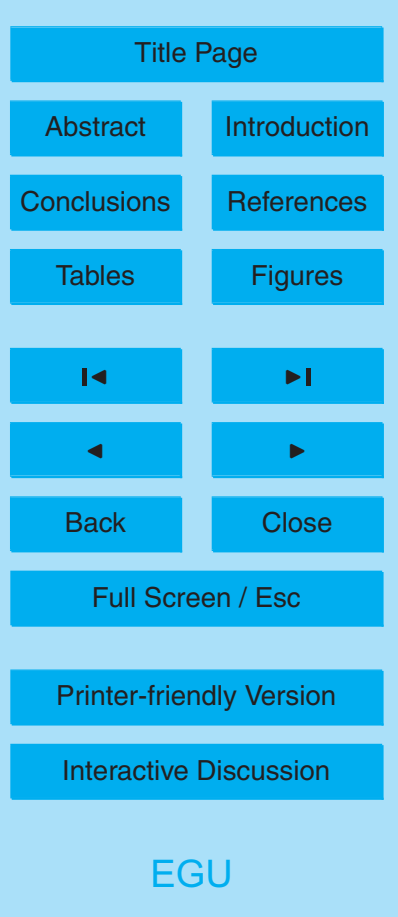


greater than that in TSP. The results suggested further that the effect of dust was more significant on fine particles than coarse particles in the atmosphere of the cities far from source regions. The sources, transport pathway, and strength of dust storm could all be the factors affecting the chemical composition of aerosol in the cities. Back tra5 jectory analysis (Draxler and Hess, 1998) at QD in Fig. 11 indicated that DS1 on 10 March and DS2 on 30 March originated from different sources and were transported along different pathways. DS1 originated from Takalimakan Desert, and then passed through region II and region IV, and finally reached QD (Fig. 11a), while DS2 arised from Gobi Deserts in Mongolia, and then passed through region III and region IV, and 10 finally to QD (Fig. 11b). DS1, along westerly direction, passed through many coalmine regions, heavy industry zones, and heavily polluted cities on the pathway, where dust clouds could mix and interact with large quantities of pollutants emitted from these areas and then carried them to QD together. However, DS2, along northwesterly direction, passed through relatively clean area, such as Northeastern Dust Region, thus it 15 would bring much less pollutants than DS1. A simple method to estimate this difference was to compare the ratio of chemical components in DS1 to those in DS2. The results indicated that nearly all chemical components in TSP in DS1 were 1-2 times as high as those in DS2. However, for those in fine particles in DS1, they were all remarkably higher than those in DS2. For example, $\mathrm{Zn}$ was $4.4, \mathrm{~Pb}$ was $6.1, \mathrm{SO}_{4}^{2-}$ and $\mathrm{NO}_{3}^{-}$were $20 \quad 4.5$ and 7.5 respectively, and the mineral components were generally $\sim 3$ times higher than those in DS2. Thus it could be seen that DS1 along the "polluted" pathway, carried more pollutants than DS2 along the "clean" pathway.

Figure 10 also indicated that the concentrations of chemical components in both DS1 and DS2 in SH were all $\sim 4$ times as high as those in non-dust storm days. The chemical components, except the ions in TSP, were a factor of 1-4 increased in DS1, while the mineral components were also a factor of 1-3 elevated in DS2, whereas the pollution elements and ions in DS2 decreased instead. The results indicated that DS1 aggravated the pollution burden of atmosphere in $\mathrm{SH}$, while DS2 diluted part of the pollutants in this region. Similar to that mentioned above, the impact of DS1 on the

\section{Regional characteristics of spring Asian dust}

Y. L. Sun et al.

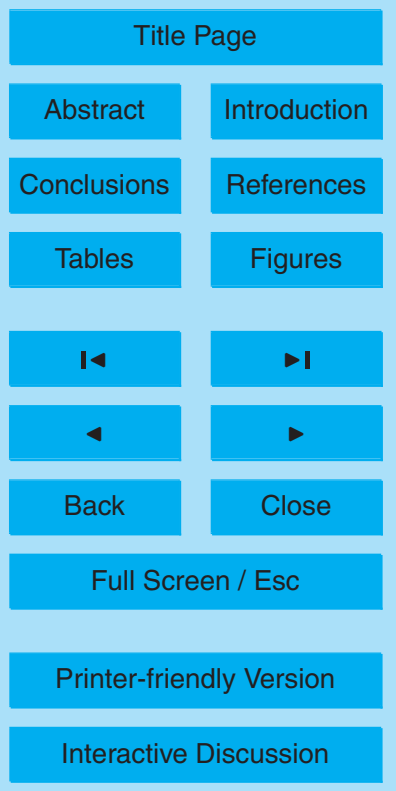

EGU 
chemical components in $\mathrm{PM}_{2.5}$ at $\mathrm{SH}$ was also more significant than those in TSP.

In conclusion, the compositional differences between dust storm and non-dust storm days revealed that (1) dust showed the most significant impact on the aerosol components in the cities near source regions and this impact decreased as the increase of

5 transport distance, i.e. YL/DL >BNU/MY>QD/SH; (2) the impact of dust on the chemical species in coarse particles near source regions was greater than that in fine particles, while in the cities far from source regions, it was more significant in fine particles; (3) the impact of dust on the mineral components was single positive effect while it was more complicated for the pollutants. Dust storm could either mix lots of pollutants on 10 the pathway and carry them to the downstream regions or dilute the pollutants in the cities. The concentrations of pollutants in the cities were somewhat determined by the strength of these two factors; (4) different dust storms showed much different impact on the aerosol components in the cities due to their different sources and transport pathways.

$15 \quad 3.4 .4$ Impact of dust on the acidity of aerosol

The $\mathrm{pH}$ of extraction solution of the aerosol can be used to denote the acidity of aerosol directly (Wang et al., 2005b). Low pH is derived from acidic components in the aerosol such as $\mathrm{SO}_{4}^{2-}, \mathrm{NO}_{3}^{-}, \mathrm{Cl}^{-}$, and some organic acids, whereas basic components such as $\mathrm{NH}_{4}^{+}, \mathrm{Mg}^{2+}$, and $\mathrm{Ca}^{2+}$ lead to the increase of $\mathrm{pH}$. The alkalinity of dust aerosol is mainly determined by calcium carbonate in it. Our early studies (Wang et al., 2005c) indicated that the larger of the size of particles, the alkalinity was stronger, that is, the higher content of carbonate in coarse particles would exhibit more capability of buffering the acidity of aerosols in the atmosphere. In order to investigate the impact of dust on the acidity of atmosphere in the cities, $\mathrm{Ca}^{2+}$ vs $\mathrm{pH}$ for each site was plotted (not shown in this paper). The results clearly showed that the alkalinity of TSP aerosol was greater than that of $\mathrm{PM}_{2.5}$. In the case of $\mathrm{BJ}$, the average $\mathrm{pH}$ of TSP aerosol in spring was 6.47 which was higher than 5.95 of $\mathrm{PM}_{2.5}$, moreover, they were both higher than the annual

\section{Regional characteristics of spring Asian dust}

Y. L. Sun et al.

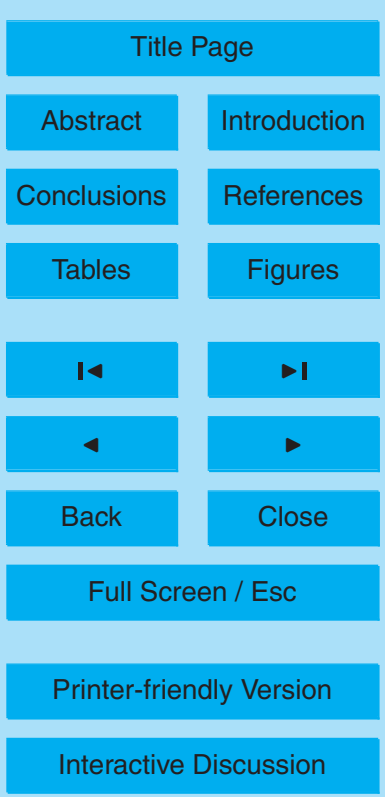


average $\mathrm{pH}$ of 5.57 (Wang et al., 2005b). Thus spring Asian dust had a significant buffering effect on the atmosphere of BJ, which could alleviate the increasing acidity of the atmosphere over the city.

The $\mathrm{pH}$ increased as the increase of concentration of $\mathrm{Ca}^{2+}$, which suggested that $5 \mathrm{Ca}^{2+}$ from mineral aerosol played an important role in buffering and neutralizing the acidity of the atmosphere over northern China. YL and DL are located near dust source regions, which are less affected by pollution sources, thus the two sites are the best places to study the buffering effect of $\mathrm{Ca}^{2+}$ on the acidity of aerosols in the cities. Hence, $\mathrm{Ca}^{2+}$ vs. $\mathrm{pH}$ at $\mathrm{YL}$ and $\mathrm{DL}$ was plotted together as shown in Fig. 12. The $\mathrm{pH}$ 10 showed strong exponential correlations with $\mathrm{Ca}^{2+}$ in both TSP $(r=0.85)$ and $\mathrm{PM}_{2.5}$ $(r=0.73)$. The results confirmed further the buffering effect of $\mathrm{Ca}^{2+}$ on the acidity of aerosols in the atmosphere. As the concentration of $\mathrm{Ca}^{2+}$ in TSP ranged from 0$15 \mu \mathrm{g} \mathrm{m}^{-3}$, the $\mathrm{pH}$, calculated from the regression equation, varied from 5.1 to 6.4 , as such, the $\mathrm{pH}$ ranged from 5.4-6.4 when the concentration of $\mathrm{Ca}^{2+}$ in $\mathrm{PM}_{2.5}$ increased 15 from $0-9 \mu \mathrm{g} \mathrm{m}^{-3}$. The $\mathrm{pH}$ of both TSP and $\mathrm{PM}_{2.5}$ showed a remarkable increase of $\sim 1$ due to the buffering effect of spring dust. The results were consistent with the simulation results that the annual mean $\mathrm{pH}$ values in northern China and Korea showed a remarkable increase of $0.8-2.5$ due to the strong neutralization of precipitation by soil aerosols over northeast Asia (Wang et al., 2002).

\section{Conclusions}

This study systematically investigated the regional characteristics of spring aerosol over northern China and the impact of spring Asian dust on aerosol chemistry of the cities. $\mathrm{PM}_{10}$ in the cities of northern China showed clear regionality, based on which the northern China could be divided into five regions, i.e. Northern Dust Region, Northeastern Dust Region, Western Dust Region, Inland Passing Region, and Coastal Region. Northern Dust Region was characterized by high content of $\mathrm{Ca}$ and Northeastern Dust Region with low concentration of $\mathrm{Ca}$ instead. Northeastern Dust Region was in the

\section{Regional characteristics of spring Asian dust}

Y. L. Sun et al.

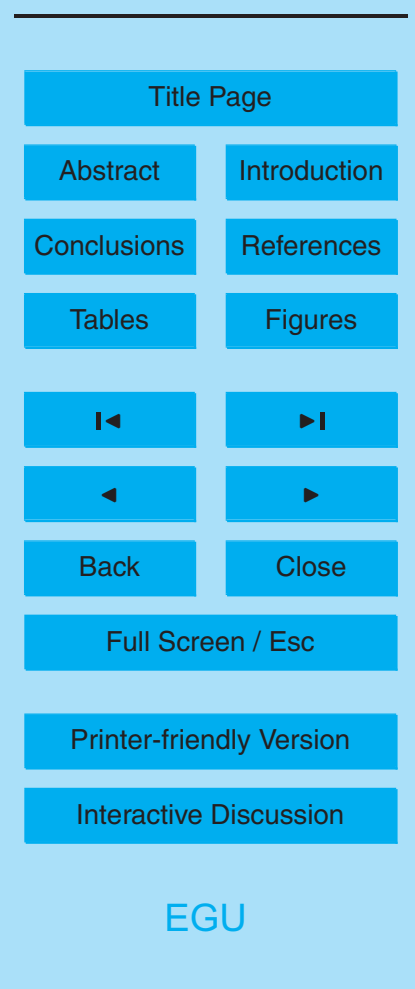


"clean" area of northern China, where the concentrations of pollutants and secondary ions were the lowest among all sites. Inland Passing Region and Coastal Region, most of developed cities are located, showed high concentrations of pollutants, of which As and $\mathrm{Pb}$ in Inland Passing Region, and $\mathrm{Na}^{+}, \mathrm{SO}_{4}^{2-}$, and $\mathrm{NO}_{3}^{-}$in Coastal Region were the 5 highest respectively. Inland Passing Region and Coastal Region are located in the "polluted" regions characterized by the increasing enrichment factors of pollution elements in $\mathrm{PM}_{2.5}$ in the order of $\mathrm{QD}>\mathrm{SH}>\mathrm{BNU}>\mathrm{MY}>\mathrm{YL}>\mathrm{DL}$. Ca/Al could be used as element tracer to identify the sources of dust storm as different sources regions showed much different content of $\mathrm{Ca}$.

10 Dust had the greatest impact on the aerosol components in the areas near source regions, and this impact decreased as the increase of transport distance, i.e. Northern Dust Region / Northeastern Dust Region (YL/DL) > Inland Passing Region (BNU/MY) $>$ Coastal Region (QD/SH). Moreover, this impact was inclined to affect the chemical components in coarse particles near source regions and those in fine particles in the cities far from source regions. Dust storm could either mix lots of pollutants on the pathway and carry them to the downstream regions or dilute the pollutants over the cities. Each dust episode corresponded to a low ratio of $\mathrm{NO}_{3}^{-} / \mathrm{SO}_{4}^{2-}$ with the lowest value appearing after the peak of dust storm. Dust, especially carbonate in it, is favorable to clear out acid matters in the atmosphere through surface reactions, and the $\mathrm{pH}$ in the aerosols over northern China in spring could increase $\sim 1$ due to the buffering effect of spring Asian dust.

Acknowledgements. This work was supported by the National Natural Science Foundation of China (Grant Nos. 30230310, 20477004, and 40575062), National 973 Project (2005CB422205), Beijing Natural Science Foundation (Grant No. 8041003), and also in part 25 supported by SKLLQG, the Institute of Earth Environment, CAS, and the Swedish International Development Cooperation Agency (SIDA) through the Asian Regional Research Program on Environmental Technology (ARRPET) at the Asian Institute of Technology.

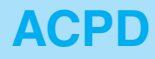

6, 12825-12864, 2006

\section{Regional characteristics of spring Asian dust}

Y. L. Sun et al.

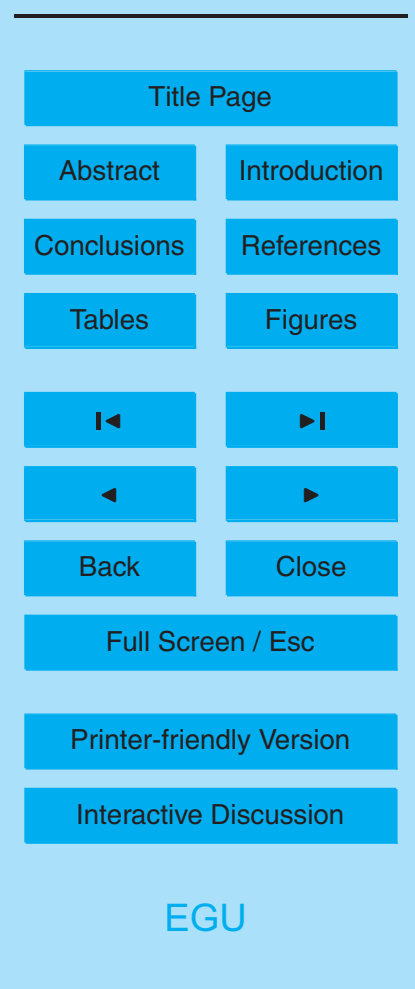




\section{References}

Arimoto, R., Duce, R. A., Savoie, D. L., Prospero, J. M., Talbot, R., Cullen, J. D., Tomza, U., Lewis, N. F., and Ray, B. J.: Relationships among aerosol constituents from Asia and the North Pacific during PEM-West A, J. Geophys. Res., 101(D1), 2011-2024, 1996.

5 Arimoto, R., Zhang, X. Y., Huebert, B. J., Kang, C. H., Savoie, D. L., Prospero, J. M., Sage, S. K., Schloesslin, C. A., Khaing, H. M., and Oh, S. N.: Chemical composition of atmospheric aerosols from Zhenbeitai, China, and Gosan, South Korea, during ACE-Asia, J. Geophys. Res., 109, D19S04, doi:10.1029/2003JD004323, 2004.

Cheng, T., Lu, D., Wang, G., and Xu, Y. : Chemical characteristics of Asian dust aerosol from Hunshan Dake Sandland in Northern China, Atmos. Environ., 39, 2903-2911, 2005.

Choi, J. C., Lee, M., Chun, Y., Kim, J., and Oh, S.: Chemical composition and source signature of spring aerosol in Seoul, Korea, J. Geophys. Res., 106(D16), 18 067-18074, 2001.

Draxler, R. R. and Hess, G. D.: An overview of the Hysplit-4 modeling system for trajectories, dispersion, and deposition, Aust. Meteorol. Mag., 47, 295-308, 1998.

15 Duan, F., Liu, X., Yu, T., and Cachier, H.: Identification and estimate of biomass burning contribution to the urban aerosol organic carbon concentrations in Beijing, Atmos. Environ., 38, 1275-1282, 2004.

Duce, R. A., Unni, C. K., and Ray, B. J.: Long range atmospheric transport of soil dust from Asia to the Tropical North Pacific: Temporal variability, Science, 209, 1522-1524, 1980.

Guo, J. H., Rahn, K. A., and Zhuang, G. S.: A mechanism for the increase of pollution elements in dust storms in Beijing, Atmos. Environ., 38, 855-862, 2004.

He, K., Yang, F., Ma, Y., Zhang, Q., Yao, X., Chan, C. K., Cadle, S., Chan, T., and Mulawa, P.: The characteristics of PM2.5 in Beijing, China, Atmos. Environ., 35, 4959-4970, 2001.

Hee, J. I. and Soon, U. P.: A simulation of long-range transport of Yellow Sand observed in April 1998 in Korea, Atmos. Environ., 36, 4173-4187, 2002.

Hseung, Y. and Jackson, K. L.: Mineral composition of the clay fraction of some main soil groups of China, Soil Sci. Soc. Am. Proc., 16, 97-110, 1952.

Huebert, B. J., Bates, T., Russell, P. B., Shi, G., Kim, Y. J., Kawamura, K., Carmichael, G., and Nakajima, T.: An overview of ACE-Asia: Strategies for quantifying the relationships between Asian aerosols and their climatic impacts, J. Geophys. Res., 108(D23), 8633, doi:10.1029/2003JD003550, 2003.

Husar, R. B., Tratt, D. M., Schichtel, B. A., Falke, S. R., Li, F., Jaffe, D., Gasso, S., Gill, T.,

\section{Regional characteristics of spring Asian dust}

Y. L. Sun et al.

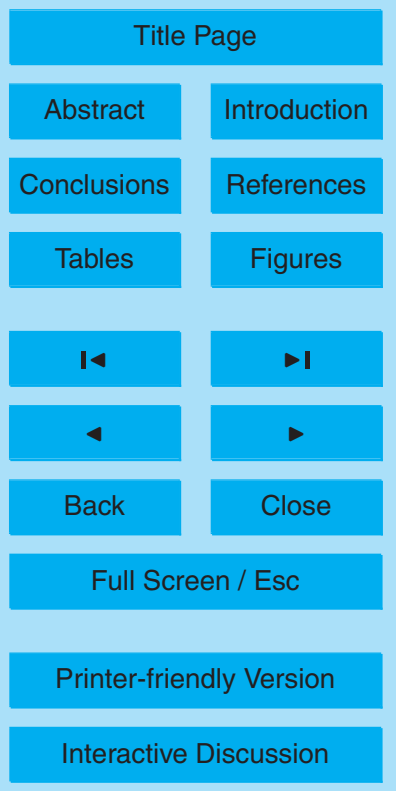


Laulainen, N. S., Lu, F., Reheis, M. C., Chun, Y., Westphal, D., Holben, B. N., Gueymard, C., McKendry, I., Kuring, N., Feldman, G. C., McClain, C., Frouin, R. J., Merrill, J., DuBois, D., Vignola, F., Murayama, T., Nickovic, S., Wilson, W. E., Sassen, K., Sugimoto, N., and Malm, W. C.: The Asian Dust Events of April 1998, J. Geophys. Res., 106(D16), 18317-18330, 52001.

Jickells, T. D., An, Z. S., Andersen, K. K., Baker, A. R., Bergametti, G., Brooks, N., Cao, J. J., Boyd, P. W., Duce, R. A., Hunter, K. A., Kawahata, H., Kubilay, N., LaRoche, J., Liss, P. S., Mahowald, N., Prospero, J. M., Ridgwell, A. J., Tegen, I., and Torres, R.: Global iron connections between desert dust, ocean biogeochemistry, and climate, Science, 308, 67$10 \quad 71,2005$.

Liu, C. L., Zhang, J., and Shen, Z. B.: Spatial and temporal variability of trace metals in aerosol from the desert region of China and the Yellow Sea, J. Geophys. Res., 107(D14), 4215, doi:10.1029/2001JD000635, 2002.

Makra, L., Borbely-Kiss, I., Koltay, E., and Chen, Y.: Enrichment of desert soil elements in Takla

15 Makan dust aerosol, Nucl. Instrum. Methods Phys. Res., Sect. B, 189, 214- 220, 2002.

Mamane, Y. and Gottlieb, J.: Nitrate formation on sea-salt and mineral particles-a single approach, Atmos. Environ., 26A, 1763-1769, 1992.

Mason, B. and Moore, C. B.: Principles of Geochemistry, 4th ed., 45-47, Wiley, New York, 1982.

20 Nishikawa, M., Kanamori, S., Kanamori, N., Mizoguchi, T.: Kosa aerosol as eolian carrier of anthropogenic material, Sci. Total Environ., 107, 13-27, 1991.

Qian, W., Tang, X., and Quan, L.: Regional characteristics of dust storms in China, Atmos. Environ., 38, 4895-4907, 2004.

Sun, Y., Zhuang, G., Yuan, H., Zhang, X., and Guo, J.: Characteristics and sources of 2002 super dust storm in Beijing, Chinese Sci. Bull, 49(7), 698-705, 2004a.

Sun, Y., Zhuang, G., Wang, Y., Han, L., Guo, J., Dan, M., Zhang, W., Wang, Z., and Hao, Z.: The air-borne particulate pollution in Beijing concentration, composition, distribution and sources, Atmos. Environ., 38, 5991-6004, 2004b.

Sun, Y., Zhuang, G., Wang, Y., Zhao, X., Li, J., Wang, Z., and An, Z.: Chemical composition of dust storms in Beijing and implications for the mixing of mineral aerosol with pollution aerosol on the pathway, J. Geophys. Res., 110, D24209, doi:10.1029/2005JD006054, 2005.

Sun, Y., Zhuang, G., Zhang, W., Wang, Y., and Zhuang, Y.: Characteristics and sources of lead pollution after phasing out leaded gasoline in Beijing, Atmos. Environ., 40, 2973-2985,

\section{Regional characteristics of spring Asian dust}

Y. L. Sun et al.

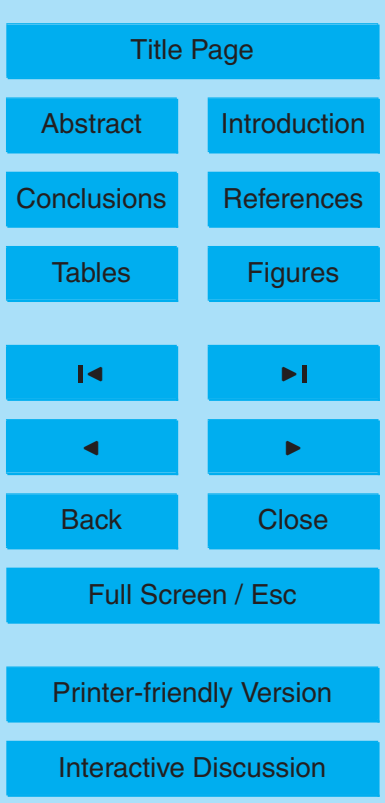

EGU 
2006.

Taylor, S. R. and McLennan, S. M.: The geochemical evolution of the continental crust, Rev. Geophys., 33, 241-265, 1995.

Uematsu, M., Yoshikawa, A., and Muraki, H.: Transport of mineral and anthropogenic aerosols during a Kosa event over East Asia, J. Geophys. Res., 107(D7), 4059, doi:10.1029/2001JD000333, 2002.

Wang, S., Wang, J. Zhou, Z., and Shang, K.: Regional characteristics of three kinds of dust storm events in China, Atmos. Environ., 39, 509-520, 2005a.

Wang, Y., Zhuang, G., Tang, A., Yuan, H., Sun, Y., Chen, S., and Zheng, A.: The ion chemistry of PM2.5 aerosol in Beijing. Atmos. Environ., 39, 3771-3784, 2005b.

Wang, Y., Zhuang, G., Sun, Y., and An, Z.: Water soluble part of the aerosol in the dust storm season - Evidence of the mixing between mineral and pollution aerosols, Atmos. Environ., 39, 7020-7029, 2005c.

Wang, Z., Akimoto, H., and Uno, I.: Neutralization of soil aerosol and its impact on the dis15 tribution of acid rain over East Asia: Observations and model results, J. Geophys. Res., 107(D19), 4389, doi:10.1029/2001JD001040, 2002.

Wei, F., Teng, E., Wu, G., Hu, W., Wilson, W. E., Chapman, R. S., Pau, J. C., and Zhang, J.: Ambient Concentrations and Elemental Compositions of PM10 and PM2.5 in Four Chinese Cities, Environ. Sci. Technol., 33, 4188-4193, 1999.

Yuan, H., Wang, Y., and Zhuang, G.: The simultaneous determination of organic acid, MSA with inorganic anions in aerosol and rainwater by ion chromatography (in Chinese), J. Instrum. Anal., 6, 12-16, 2003.

Zhang, D., Zang, J., Shi, G., Iwasaka, Y., Matsuki, A., and Trochkine, D.: Mixture state of individual Asian dust particles at a coastal site of Qingdao, China, Atmos. Environ., 37, 25 3895-3901, 2003a.

Zhang, J., Wu, Y., Liu, C., Shen, Z., Yu, Z., and Zhang, Y.: Aerosol characters from the desert region of Northwest China and the Yellow Sea in spring and summer: observations at Minqin, Qingdao, and Qianliyan in 1995-1996, Atmos. Environ., 35, 5007-5018, 2001.

Zhang, X. Y., Gong, S. L., Shen, Z. X., Mei, F. M., Xi, X. X., Liu, L. C., Zhou, Z. J., Wang, D., Wang, Y. Q., and Cheng, Y.: Characterization of soil dust aerosol in China and its transport and distribution during 2001 ACE-Asia: 1. Network observations, J. Geophys. Res., 108(D9), 4261, doi:10.1029/2002JD002632, 2003b.

Zhang, X., Zhang, G., Zhu, G., Zhang, D., An, Z., Chen, T., and Huang, X.: Elemental tracers

\section{Regional characteristics of spring Asian dust}

Y. L. Sun et al.

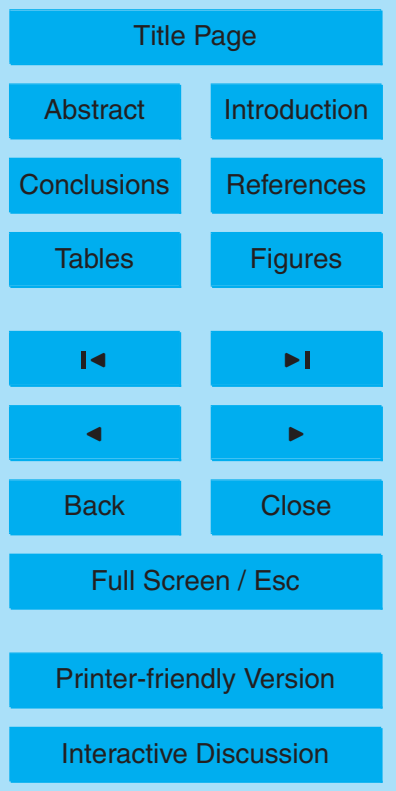


for Chinese source dust, Sci. China, Ser. D, 39(5), 512-521, 1997.

Zhang, X., Zhuang, G., and Yuan, H.: The dried salt-lakes saline soils sources of the dust storm in Beijing-the individual particles analysis and XPS surface structure analysis (in Chinese), China Environ. Sci., 24(5), 533-537, 2004.

5 Zheng, C. J.: Atlas of Soil Environmental Background Value in the People's Republic of China. China Environmental Science Press, Beijing. p.139, 1994.

Zhuang, G., Guo, J., Yuan, H., and Zhao, C.: The compositions, sources, and size distribution of the dust storm from China in spring of 2000 and its impact on the global environment, Chinese Sci. Bull., 46(11), 895-901, 2001.

10 Zhuang, G., Yi, Z., Duce, R. A., and Brown, P. R.: Link between iron and sulfur cycles suggested by detection of iron (II) in remote marine aerosols, Nature, 355, 537-539, 1992.

\section{ACPD}

6, 12825-12864, 2006

\section{Regional characteristics of spring Asian dust}

Y. L. Sun et al.

Title Page

Abstract

Introduction

Conclusions

References

Tables

Figures

14

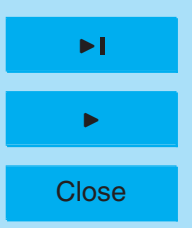

Back

Full Screen / Esc

Printer-friendly Version

Interactive Discussion 
Table 1. Varimax rotated factor loading matrix for $\mathrm{PM}_{10}$ in 13 cities in northern China ${ }^{\mathrm{a}}$.

\begin{tabular}{ccccc}
\hline Cities & Factor 1 & Factor 2 & Factor 3 & Factor 4 \\
\hline Beijing & 0.19 & -0.09 & $\mathbf{0 . 9 0}$ & -0.05 \\
Hohhot & 0.22 & 0.11 & $\mathbf{0 . 7 8}$ & 0.08 \\
Lanzhou & $\mathbf{0 . 8 2}$ & 0.07 & 0.19 & 0.23 \\
Qingdao & 0.16 & $\mathbf{0 . 8 5}$ & 0.02 & 0.09 \\
Shanghai & 0.02 & $\mathbf{0 . 8 4}$ & 0.04 & -0.02 \\
Shenyang & 0.06 & $\mathbf{0 . 7 3}$ & 0.35 & -0.12 \\
Shijiazhuang & 0.34 & 0.12 & $\mathbf{0 . 7 7}$ & -0.13 \\
Taiyuan & -0.02 & 0.18 & $\mathbf{0 . 7 7}$ & 0.01 \\
Tianjin & 0.15 & 0.13 & $\mathbf{0 . 8 6}$ & -0.06 \\
Urumchi & 0.05 & -0.02 & -0.07 & $\mathbf{0 . 9 4}$ \\
Xi'an & $\mathbf{0 . 7 1}$ & 0.18 & 0.02 & -0.18 \\
Xining & $\mathbf{0 . 8 6}$ & 0.09 & 0.18 & 0.18 \\
Yinchuan & $\mathbf{0 . 7 7}$ & -0.08 & 0.35 & -0.14 \\
Expl.Var & 2.75 & 2.10 & 3.69 & 1.09 \\
Prp.Totl & 0.21 & 0.16 & 0.28 & 0.08 \\
\hline
\end{tabular}

6, 12825-12864, 2006

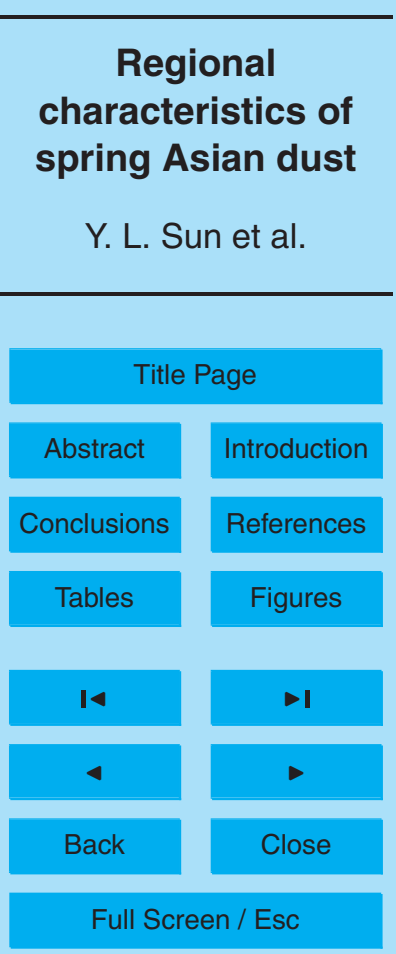

${ }^{a}$ Factor loadings larger than 0.70 are marked in bold. 


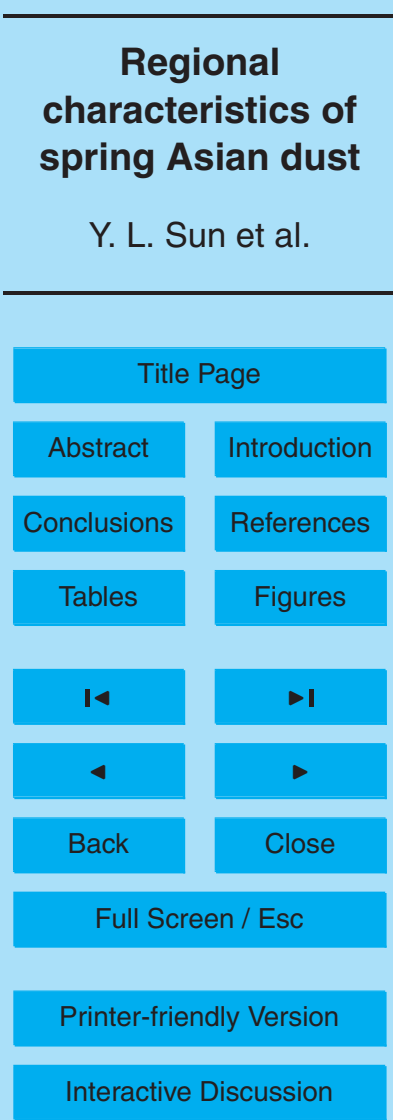

Table 2. Meteorological conditions in the five cities in the spring of 2004.

\begin{tabular}{lccccc}
\hline & Shanghai & Qingdao & Beijing & Duolun & Yulin \\
\hline Pressure $(\mathrm{kPa})$ & 101.7 & 100.8 & 101.2 & 87.3 & 88.5 \\
Wind Speed $(\mathrm{m} / \mathrm{s})$ & 3.7 & 4.4 & 2.9 & 4.1 & 2.9 \\
Temperature $\left({ }^{\circ}\right)$ & 13.1 & 9.2 & 12.2 & 1.9 & 9.1 \\
Relative Humidity $(\%)$ & 66.6 & 64.2 & 33.1 & 33.8 & 25.2 \\
Precipitation $(\mathrm{mm})$ & 28.2 & 9.6 & 6.3 & 3.3 & 2.6 \\
\hline
\end{tabular}

Interactive Discussion 


\section{ACPD}

6, 12825-12864, 2006

Table 3. Ratios of Fe/Al, Mg/Al, and $\mathrm{Ca} / \mathrm{Al}$ in $\mathrm{TSP}$ and $\mathrm{PM}_{2.5}$ at six sampling sites.

\begin{tabular}{|c|c|c|c|c|c|c|c|}
\hline Sites & $\begin{array}{l}\text { TSP } \\
\mathrm{Fe} / \mathrm{Al}\end{array}$ & $\mathrm{Mg} / \mathrm{Al}$ & $\mathrm{Ca} / \mathrm{Al}$ & $\begin{array}{r}\mathrm{PM}_{2.5} \\
\mathrm{Fe} / \mathrm{Al}\end{array}$ & $\mathrm{Mg} / \mathrm{Al}$ & $\mathrm{Ca} / \mathrm{Al}$ & Reference \\
\hline YL & 0.65 & 0.27 & 1.64 & 0.70 & 0.30 & 1.71 & This study \\
\hline $\mathrm{DL}$ & 0.62 & 0.18 & 0.61 & 0.60 & 0.21 & 0.79 & \\
\hline MY & 0.63 & 0.32 & 1.01 & 0.85 & 0.33 & 1.17 & \\
\hline BNU & 1.03 & 0.35 & 2.27 & 1.00 & 0.29 & 1.55 & \\
\hline QD & 0.62 & 0.21 & 0.95 & 0.79 & 0.27 & 0.83 & \\
\hline $\mathrm{SH}$ & 0.71 & 0.21 & 1.60 & 0.98 & 0.31 & 1.09 & \\
\hline Crust & 0.62 & 0.26 & 0.45 & & & & Mason and Moore (1982) \\
\hline YL & 0.48 & 0.29 & 1.48 & & & & Zhang et al. (1997) \\
\hline Dingbian $^{a}$ & 0.93 & 0.22 & 1.97 & & & & Zhang et al. (1997) \\
\hline$B J^{b}$ & & & & 1.43 & 0.28 & 1.54 & He et al. (2001) \\
\hline Sanggen Dalai ${ }^{\mathrm{C}}$ & 0.85 & 0.26 & 0.64 & & & & Cheng et al. (2005) \\
\hline Taklimakan Desert & 1.34 & $N D^{d}$ & 3.07 & & & & Makra et al. (2002) \\
\hline $\mathrm{Aksu}^{\mathrm{e}}$ & 1.04 & 0.50 & 2.04 & & & & Zhang et al. (2003) \\
\hline
\end{tabular}

\section{Regional characteristics of spring Asian dust}

Y. L. Sun et al.

Title Page

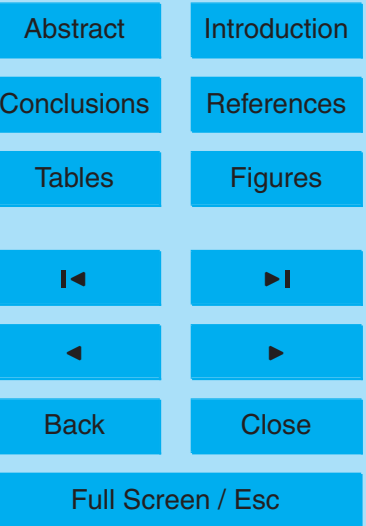

Printer-friendly Version

Interactive Discussion 


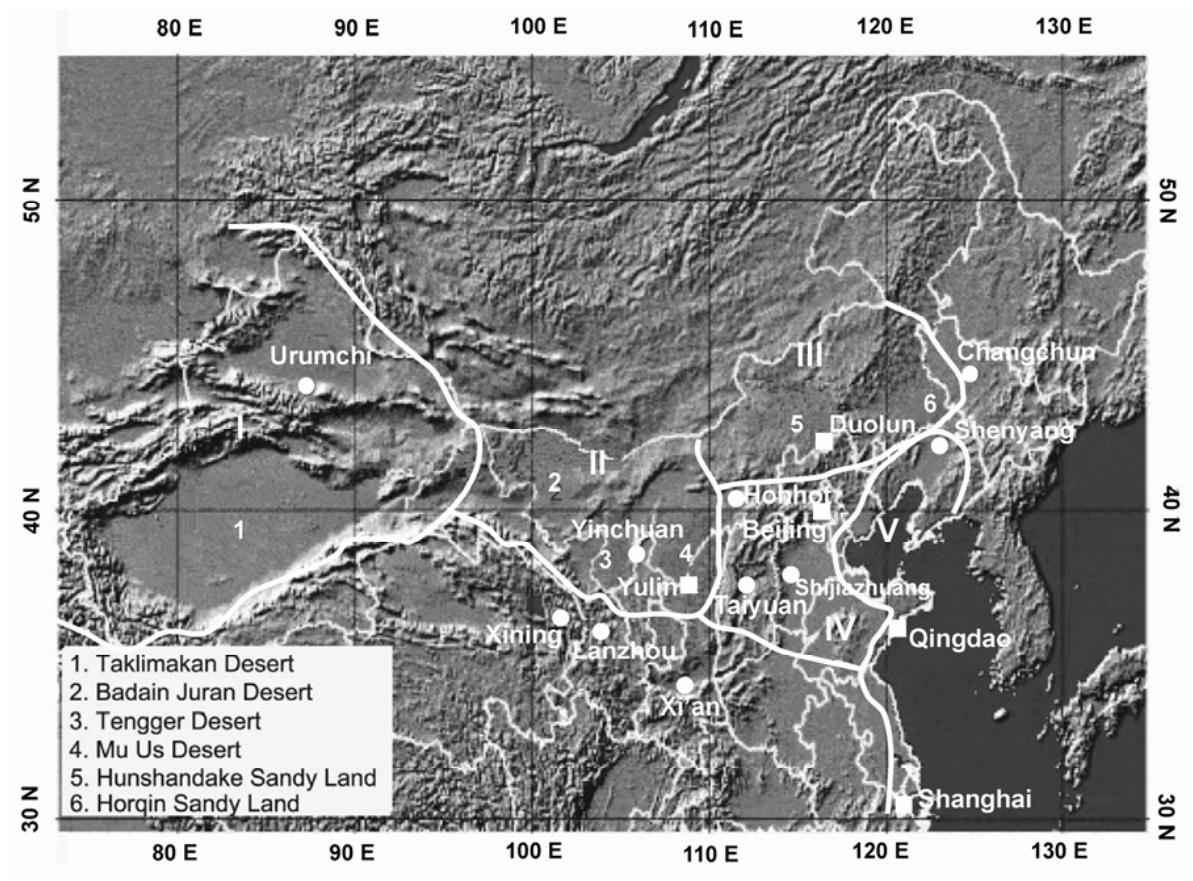

Fig. 1. Regional division of the cities over northern China in the spring of 2004 (I: Western-Dust Region; II: Northern Dust Region; III: Northeastern Dust Region; IV: Inland Passing Region; V: Coastal Region). The sampling sites are marked in squares.
ACPD

6, 12825-12864, 2006

\section{Regional characteristics of spring Asian dust}

Y. L. Sun et al.

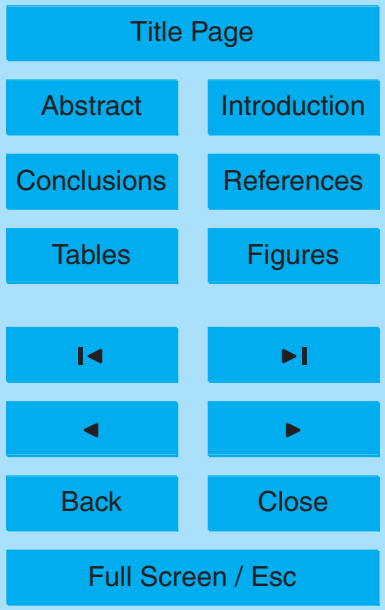

Printer-friendly Version

Interactive Discussion 

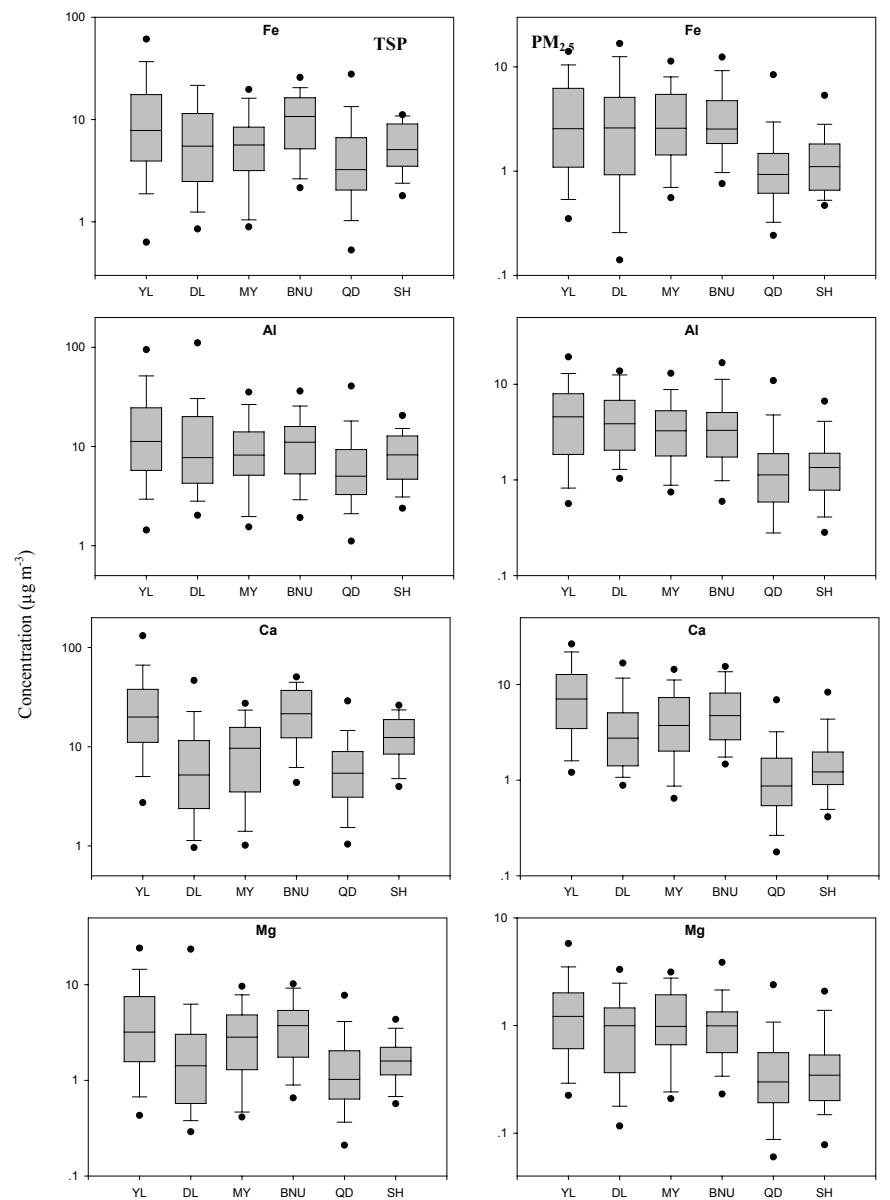

Fig. 2. The spatial variations of $\mathrm{Fe}, \mathrm{Al}, \mathrm{Ca}$, and $\mathrm{Mg}$ in TSP and $\mathrm{PM}_{2.5}$ in the spring of 2004. The ends of the box, the ends of the whiskers, and the line across each box represent the 25th and 75th percentiles, the 5th and 95th percentiles, and the median, respectively.

\section{ACPD}

6, 12825-12864, 2006

\section{Regional characteristics of spring Asian dust}

Y. L. Sun et al.

Title Page

Abstract

Introduction

Conclusions

References

Tables

Figures

14

4

Back

Close

Full Screen / Esc

Printer-friendly Version

Interactive Discussion 

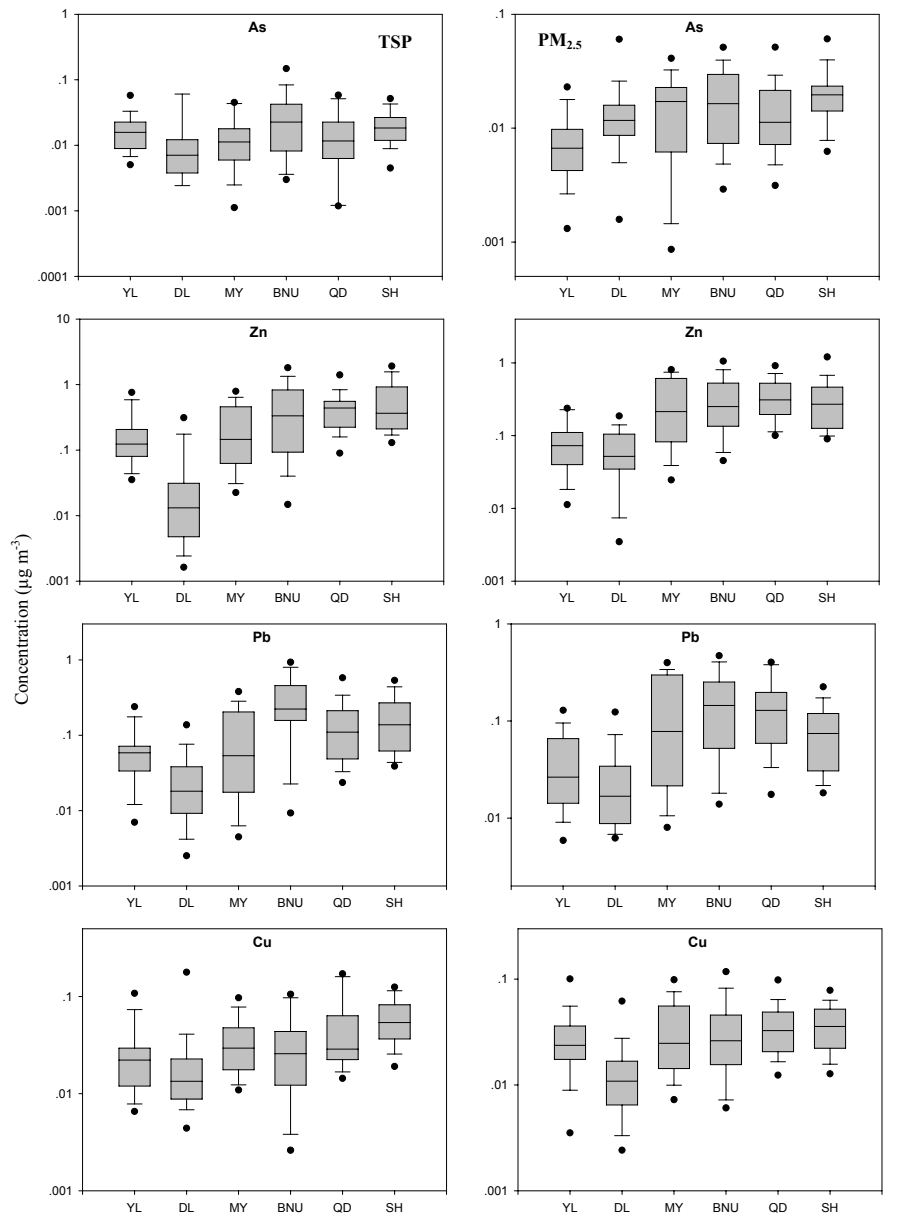

ACPD

$6,12825-12864,2006$

\section{Regional characteristics of spring Asian dust}

\section{Y. L. Sun et al.}

Title Page

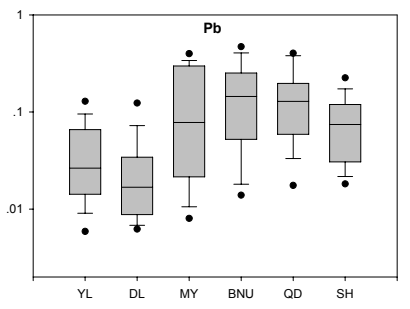

Conclusions

References

Tables

Figures

14

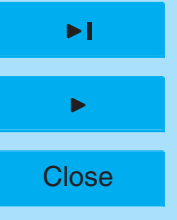

Back

Close

Full Screen / Esc

Printer-friendly Version

Interactive Discussion

Fig. 3. The spatial variations of pollution elements $\mathrm{As}, \mathrm{Zn}, \mathrm{Pb}$, and $\mathrm{Cu}$ in the spring of 2004. The denotation of box plot is the same as those in Fig. 2.

\section{5}




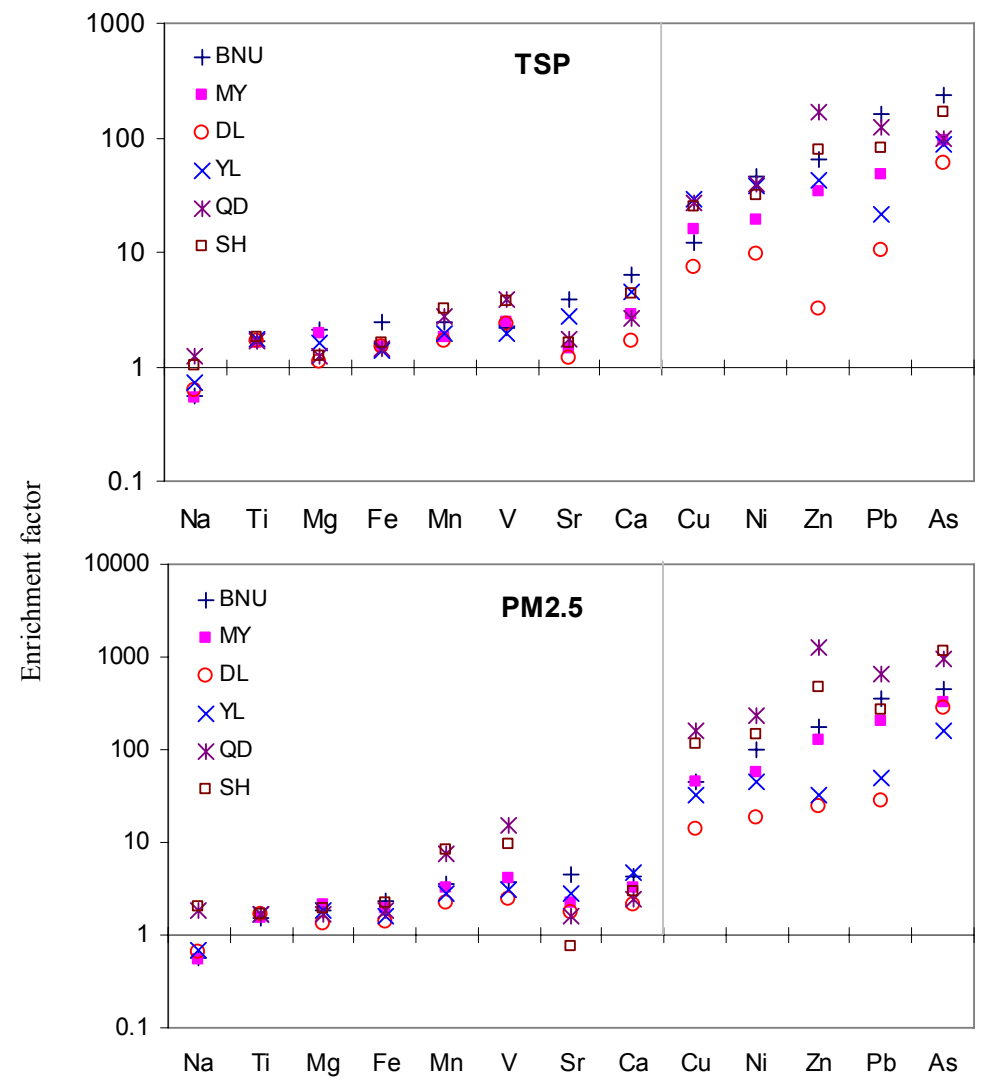

$6,12825-12864,2006$

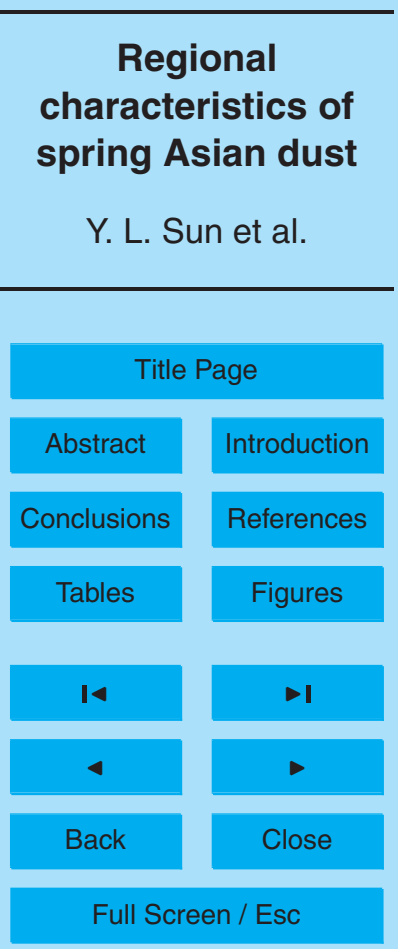

Printer-friendly Version

Fig. 4. Enrichment factors of the elements in TSP and $\mathrm{PM}_{2.5}$ in the spring of 2004.

Interactive Discussion 

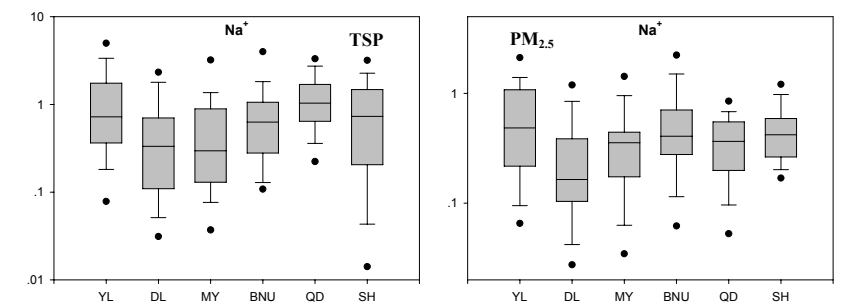

\section{ACPD}

6, 12825-12864, 2006
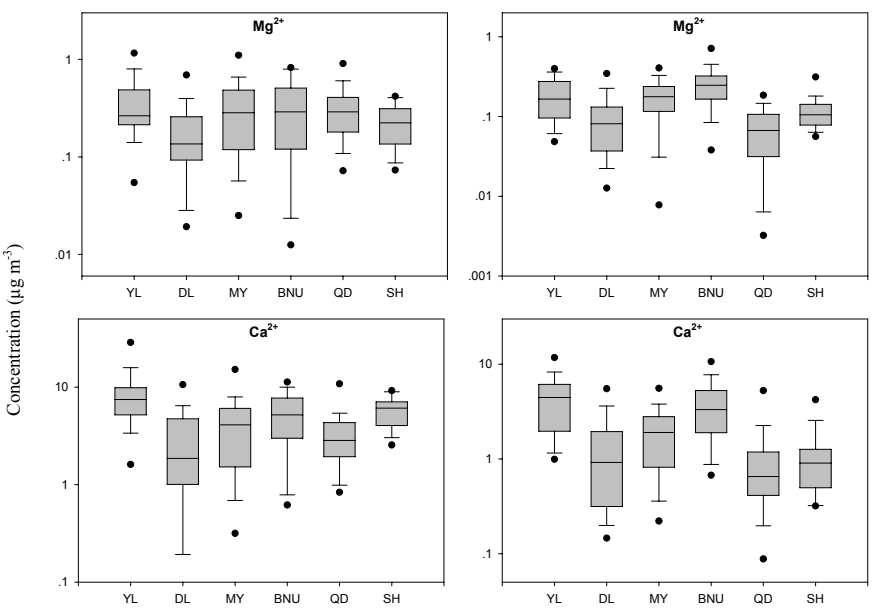

Regional characteristics of spring Asian dust

Y. L. Sun et al.

Title Page

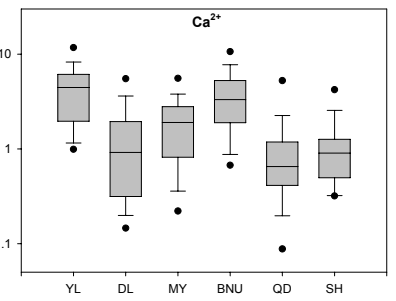

Abstract

Introduction

Conclusions

References

Tables

Figures
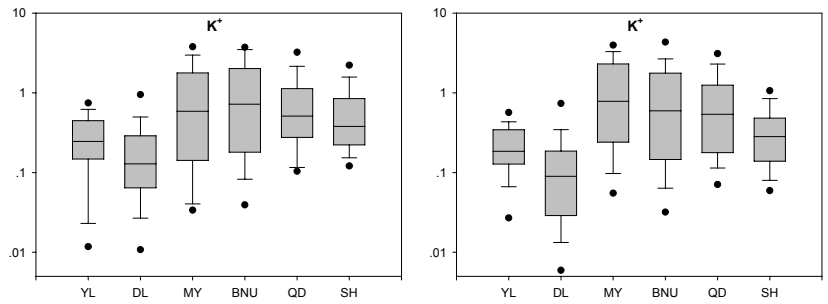

14

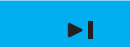

4

Back

Close

\section{Full Screen / Esc}

Printer-friendly Version

Interactive Discussion

EGU

Fig. 5. The spatial variations of $\mathrm{Na}^{+}, \mathrm{Mg}^{2+}, \mathrm{Ca}^{2+}$, and $\mathrm{K}^{+}$in TSP and $\mathrm{PM}_{2.5}$ in the spring of 2004. The denotation of box plot is the same as those in Fig. 2. 

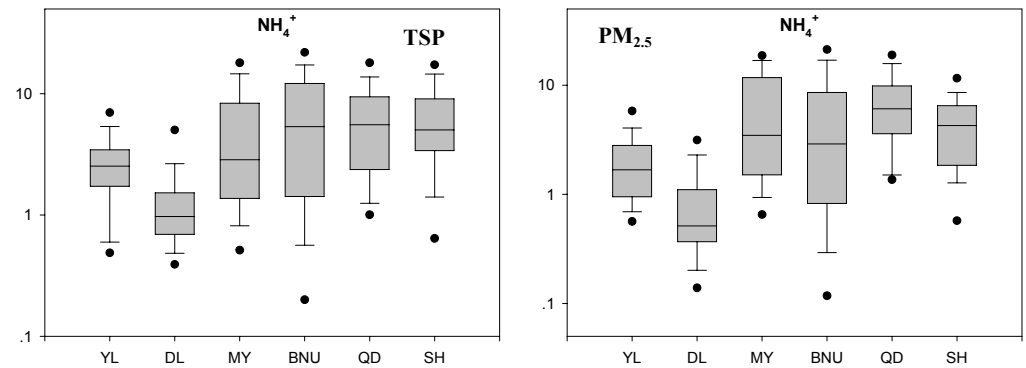

\section{ACPD}

6, 12825-12864, 2006
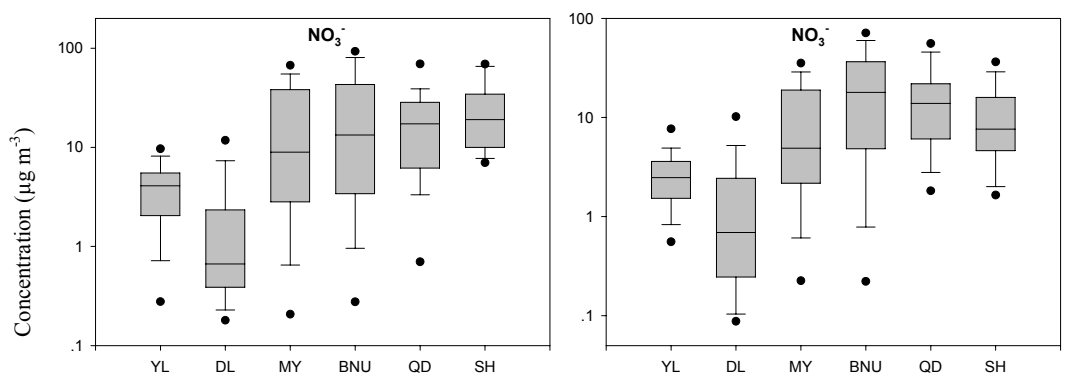

\section{Regional characteristics of spring Asian dust}

Y. L. Sun et al.
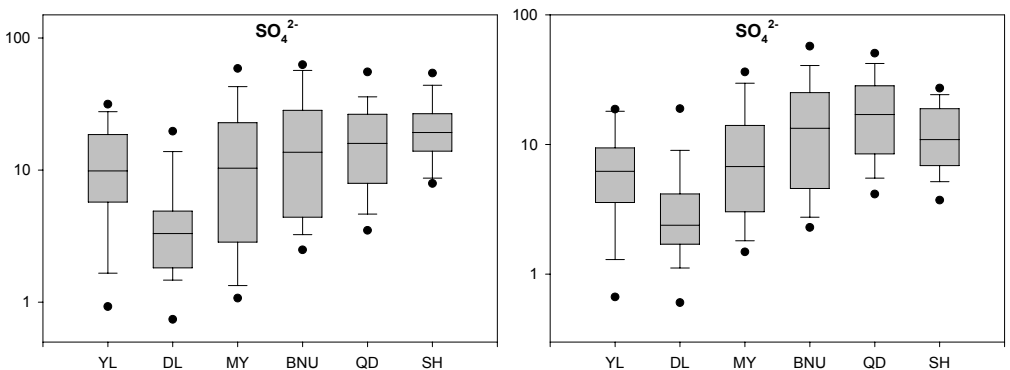

Title Page

Abstract

Introduction

Conclusions

References

Tables

Figures

14

I

4

Back

Close

\section{Full Screen / Esc}

Printer-friendly Version

Interactive Discussion 


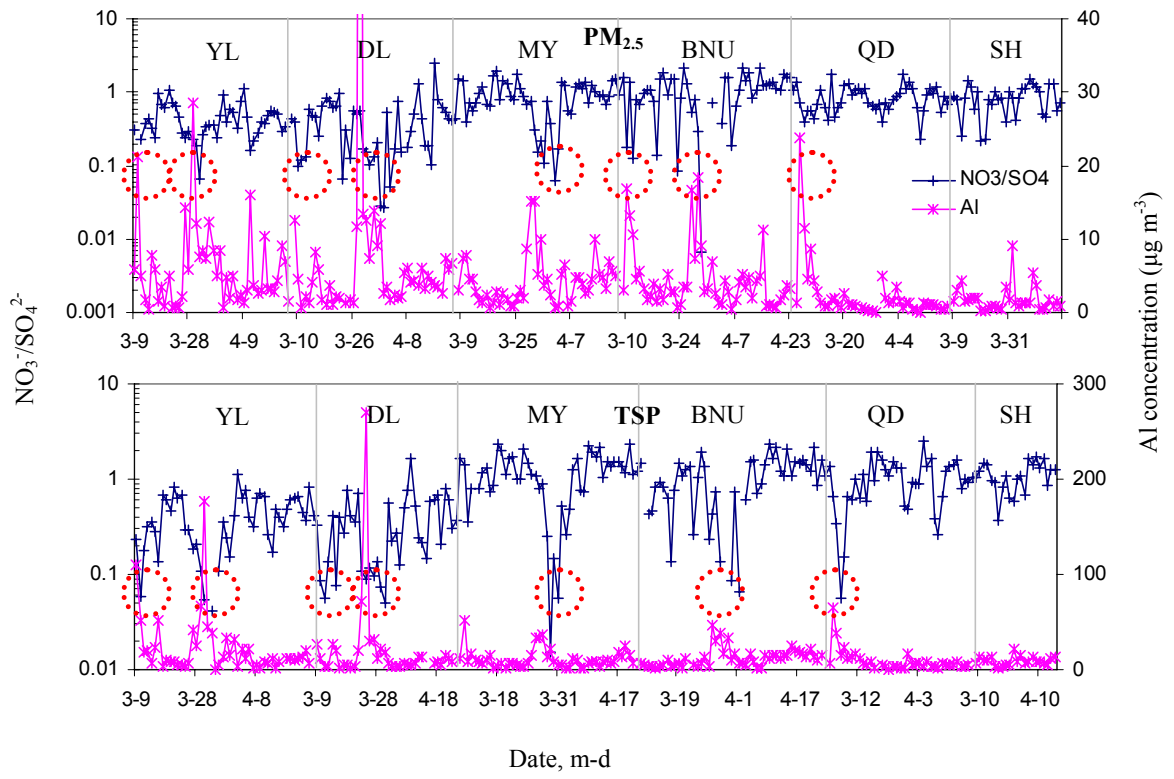

Fig. 7. Ratios of $\mathrm{NO}_{3}^{-} / \mathrm{SO}_{4}^{2-}$ and concentration of $\mathrm{Al}$ at six sites in the spring of 2004. Circles represent dust storm episodes.

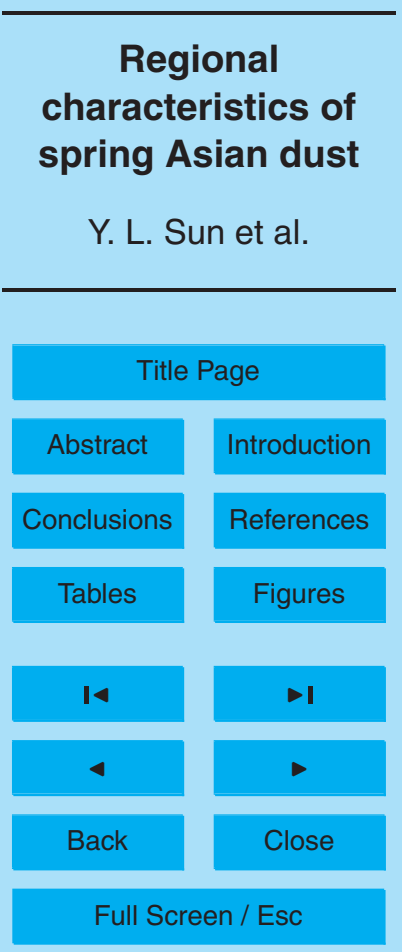

Printer-friendly Version

Interactive Discussion 


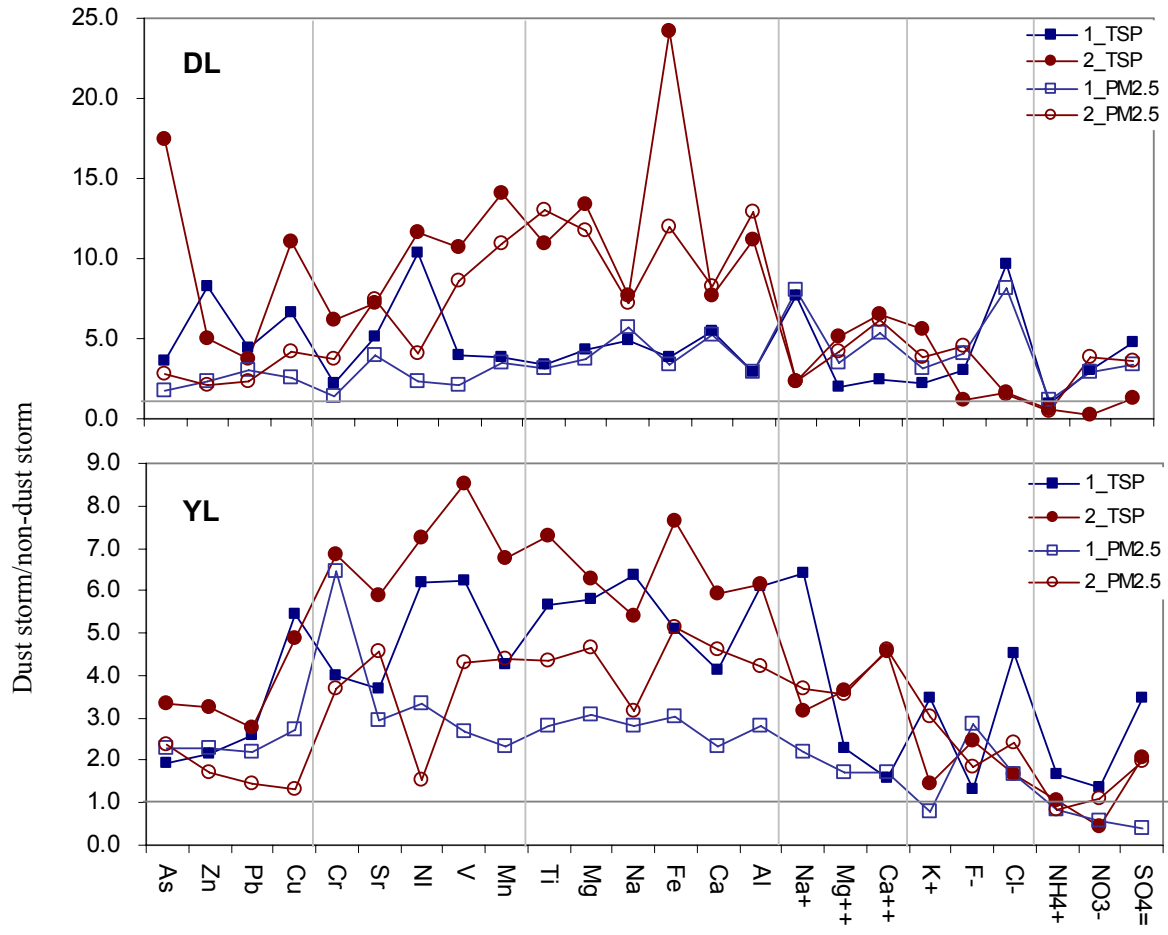

Fig. 8. Comparison of chemical composition of TSP and $\mathrm{PM}_{2.5}$ between dust storm and nondust storm days at $D L$ and $Y L$ in the spring of 2004. 1 and 2 in 1_TSP, 2_TSP, 1_PM 2.5 , and 2_PM 2.5 refers to DS1 and DS2, respectively.
ACPD

6, 12825-12864, 2006

\section{Regional characteristics of spring Asian dust}

Y. L. Sun et al.

Title Page

Abstract

Introduction

Conclusions

References

Tables

Figures

14

$>1$

4

Back

Close

Full Screen / Esc

Printer-friendly Version

Interactive Discussion 


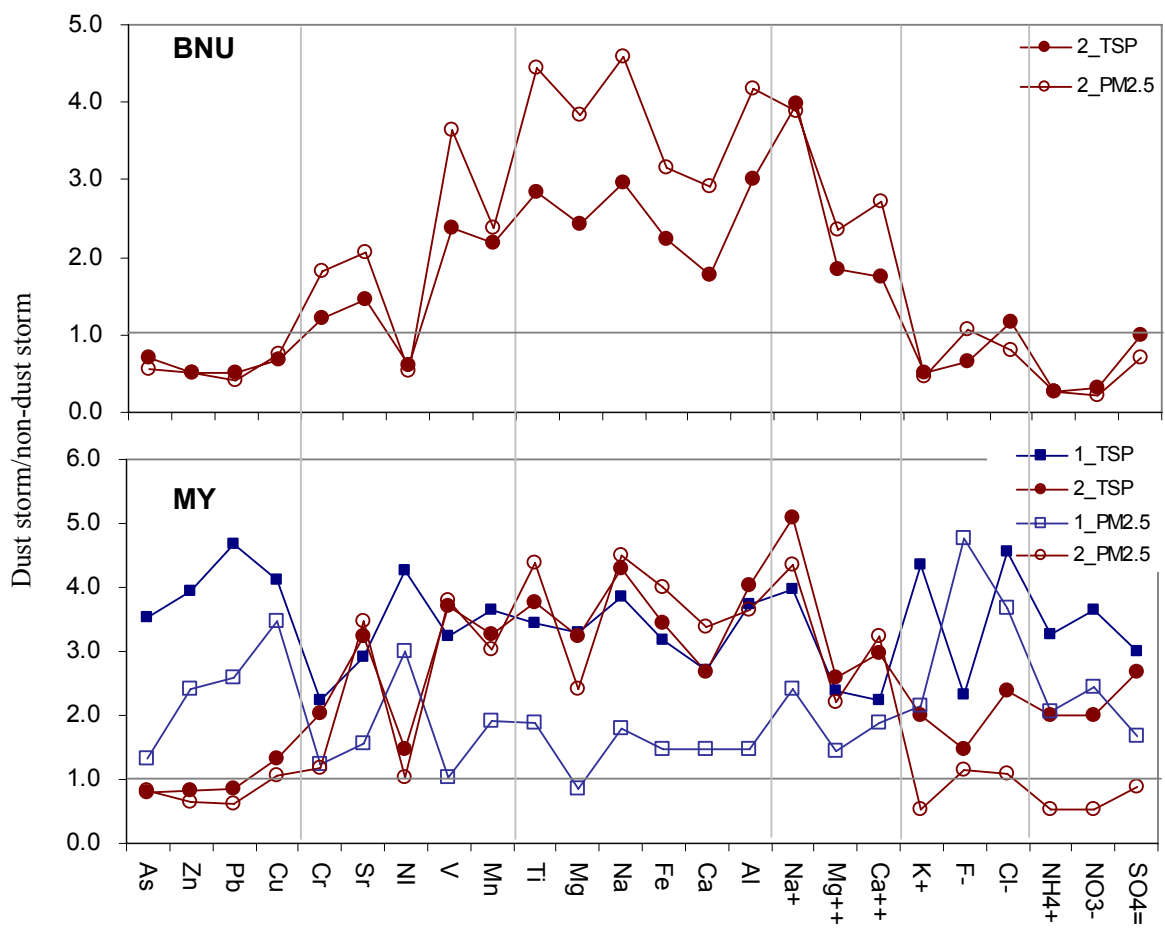

Fig. 9. Comparison of chemical composition of TSP and $\mathrm{PM}_{2.5}$ between dust storm and nondust storm days at BNU and MY in the spring of 2004. The legends are the same as those in Fig. 8.
ACPD

6, 12825-12864, 2006

\section{Regional characteristics of spring Asian dust}

Y. L. Sun et al.

Title Page

Abstract

Introduction

Conclusions

References

Tables

Figures

14

$>1$

4

Back

Close

Full Screen / Esc

Printer-friendly Version

Interactive Discussion 


\section{ACPD}

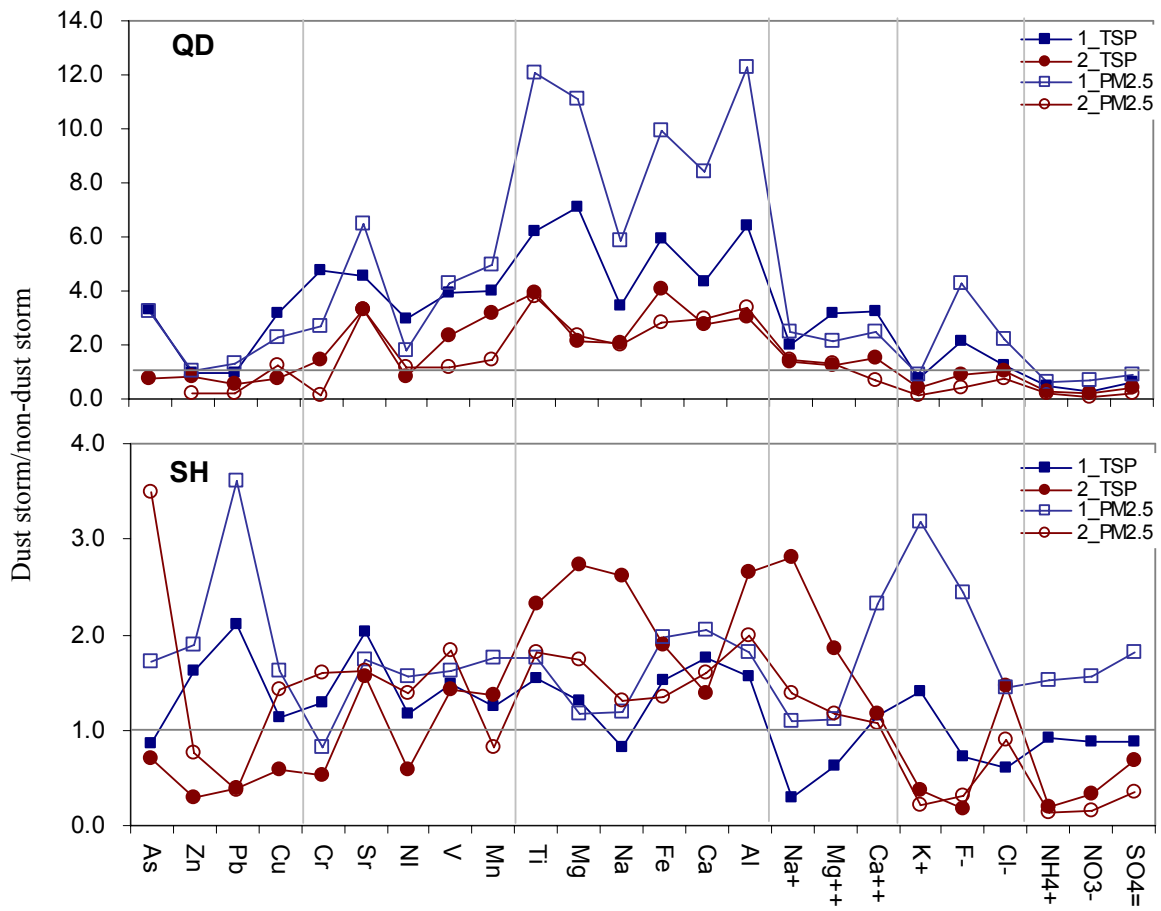

6, 12825-12864, 2006

\section{Regional characteristics of spring Asian dust}

Y. L. Sun et al.

Title Page

Abstract

Introduction

Conclusions

References

Tables

Figures

14

4

Back

Close

Full Screen / Esc

Fig. 10. Comparison of chemical composition of TSP and $\mathrm{PM}_{2.5}$ between dust storm and nondust storm days at QD and SH in the spring of 2004. The legends are the same as those in Fig. 8. 


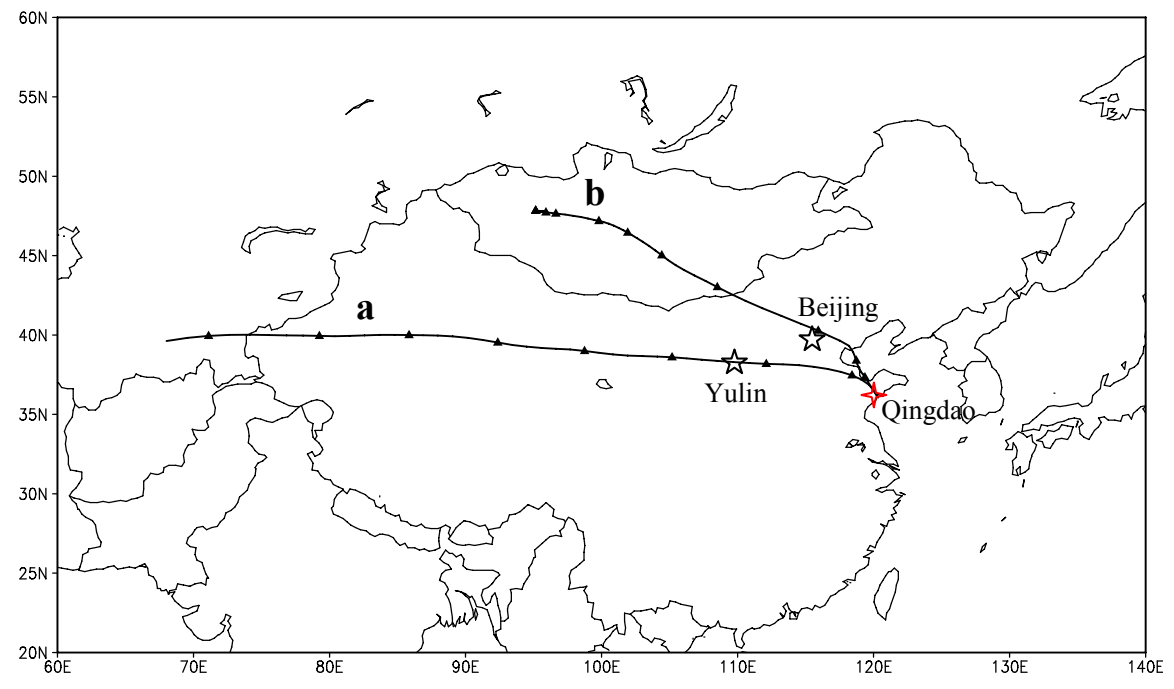

Fig. 11. $48-\mathrm{h}$ isentropic backward-trajectories ( $1 \mathrm{~km}$ altitude) calculated by NOAA HYSPLIT Model (http://www.noaa.gov) at LST 12:00 on 10 March (a) and 30 March (b) respectively for Qingdao.

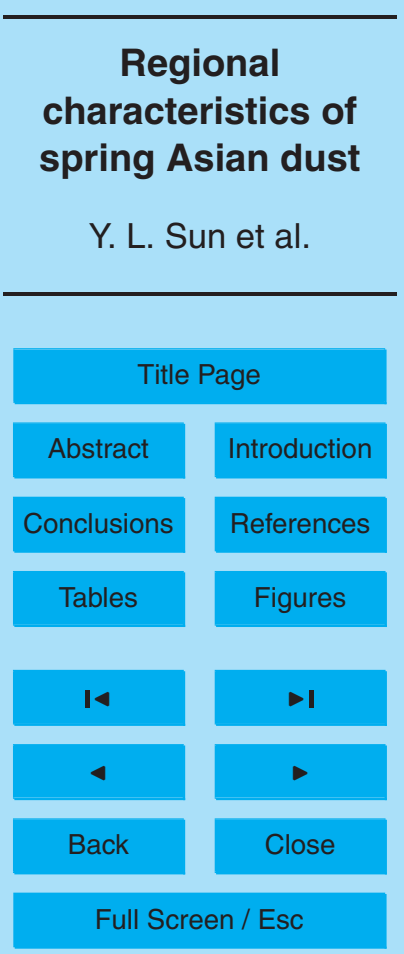

Printer-friendly Version

Interactive Discussion 


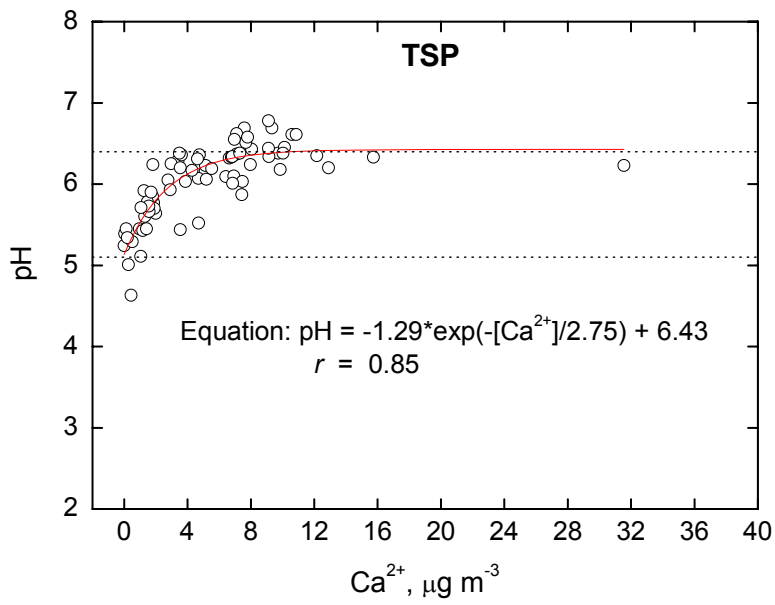

\section{ACPD}

6, 12825-12864, 2006

\section{Regional characteristics of spring Asian dust}

Y. L. Sun et al.

Title Page

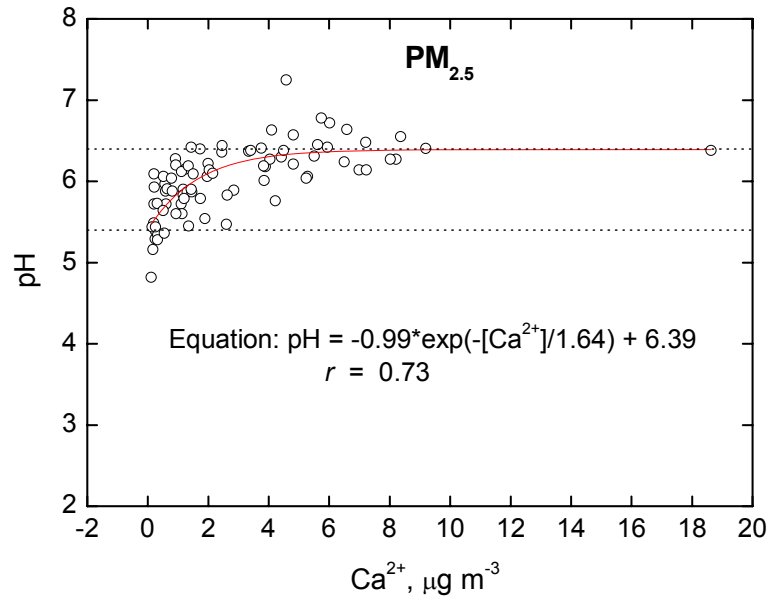

Abstract

Introduction

Conclusions

References

Tables

Figures

14

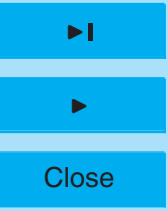

Back

Full Screen / Esc

Printer-friendly Version

Interactive Discussion

Fig. 12. Correlations between $\mathrm{pH}$ and $\mathrm{Ca}^{2+}$ in $\mathrm{TSP}$ and $\mathrm{PM}_{2.5}$ near dust source regions. 